\title{
Review
}

\section{Functional Neurophysiological Biomarkers of Early-Stage Alzheimer's Disease: A Perspective of Network Hyperexcitability in Disease Progression}

\author{
Sean Tok ${ }^{\mathrm{a}, \mathrm{b}, *}$, Abdallah Ahnaou ${ }^{\mathrm{a}}$ and Wilhelmus Drinkenburg ${ }^{\mathrm{a}, \mathrm{b}}$ \\ ${ }^{a}$ Department of Neuroscience, Janssen Research \& Development, Janssen Pharmaceutica NV, Beerse, Belgium \\ ${ }^{\mathrm{b}}$ Groningen Institute for Evolutionary Life Sciences, Faculty of Science and Engineering, \\ University of Groningen, The Netherlands
}

Accepted 19 July 2021

Pre-press 20 August 2021

\begin{abstract}
Network hyperexcitability $(\mathrm{NH})$ has recently been suggested as a potential neurophysiological indicator of Alzheimer's disease (AD), as new, more accurate biomarkers of $\mathrm{AD}$ are sought. NH has generated interest as a potential indicator of certain stages in the disease trajectory and even as a disease mechanism by which network dysfunction could be modulated. NH has been demonstrated in several animal models of AD pathology and multiple lines of evidence point to the existence of $\mathrm{NH}$ in patients with $\mathrm{AD}$, strongly supporting the physiological and clinical relevance of this readout. Several hypotheses have been put forward to explain the prevalence of $\mathrm{NH}$ in animal models through neurophysiological, biochemical, and imaging techniques. However, some of these hypotheses have been built on animal models with limitations and caveats that may have derived NH through other mechanisms or mechanisms without translational validity to sporadic $\mathrm{AD}$ patients, potentially leading to an erroneous conclusion of the underlying cause of $\mathrm{NH}$ occurring in patients with $\mathrm{AD}$. In this review, we discuss the substantiation for $\mathrm{NH}$ in animal models of AD pathology and in human patients, as well as some of the hypotheses considering recently developed animal models that challenge existing hypotheses and mechanisms of $\mathrm{NH}$. In addition, we provide a preclinical perspective on how the development of animal models incorporating AD-specific NH could provide physiologically relevant translational experimental data that may potentially aid the discovery and development of novel therapies for $\mathrm{AD}$.
\end{abstract}

Keywords: Alzheimer's disease, amyloid, biomarkers, epilepsy, hippocampus, hyperexcitability, laboratory animal models, tau proteins, translational research

\section{INTRODUCTION}

Network overexcitability or hyperexcitability $(\mathrm{NH})$, a state in which neural networks exhibit an

\footnotetext{
${ }^{*}$ Correspondence to: Sean Tok, Department of Neuroscience, Janssen Research \& Development, Janssen Pharmaceutica NV, Turnhoutseweg 30, 2340 Beerse, Belgium. Tel.: +32 4704691 04; E-mail: Stok@its.jnj.com.
}

increased likelihood to be excited or activated, is a mainstay in several forms of epilepsy and seizurerelated disorders. One possible cellular basis for this state of hyperexcitability originates from the excitability of excitatory neurons [1], and may stem from factors intrinsic to the neuron, such as the availability of synaptic neurotransmitter receptors, or extrinsic factors such as disinhibition from inhibitory interneuron activity [2] or astrocytic clearance of 
Table 1

List of neurodegenerative disorders linked to network hyperexcitability

\begin{tabular}{|c|c|c|c|}
\hline Disorder & Cognitive and physiological symptoms & $\begin{array}{l}\text { Regions of hyper- } \\
\text { excitability }\end{array}$ & Reference \\
\hline $\begin{array}{l}\text { Alzheimer's } \\
\text { disease }\end{array}$ & $\begin{array}{l}\text { Intellectual impairment, memory and attention deficits, } \\
\text { language impairment, visuospatial deficits, learning } \\
\text { deficits, gait disturbances, seizures, sleep disorders. }\end{array}$ & $\begin{array}{l}\text { Cortical regions, } \\
\text { temporal lobes, } \\
\text { default mode } \\
\text { network, motor } \\
\text { cortex }\end{array}$ & $\begin{array}{l}{[22,70,77,} \\
242-245]\end{array}$ \\
\hline $\begin{array}{l}\text { Amyotrophic } \\
\text { lateral sclerosis }\end{array}$ & $\begin{array}{l}\text { Muscle weakness, twitches, cramps, spasticity, slurred } \\
\text { speech, difficulty in fine motor control. }\end{array}$ & $\begin{array}{l}\text { Motor cortex, } \\
\text { peripheral } \\
\text { motor neurons }\end{array}$ & {$[246,247]$} \\
\hline $\begin{array}{l}\text { Epilepsy } \\
\text { syndrome }\end{array}$ & $\begin{array}{l}\text { Seizures, loss of muscle control, loss of consciousness, } \\
\text { memory and attention deficits, language deficits, } \\
\text { deficits in mental acuity, learning deficits, sleep } \\
\text { disorders. }\end{array}$ & $\begin{array}{l}\text { Temporal lobes, } \\
\text { cortical regions }\end{array}$ & {$[29,248-252]$} \\
\hline $\begin{array}{l}\text { Fragile X } \\
\text { Syndrome }\end{array}$ & $\begin{array}{l}\text { Intellectual impairment, memory impairments, deficits } \\
\text { in spatial visualization, visuo-motor coordination, } \\
\text { language deficits, seizures, attention deficits, } \\
\text { hyperactivity, low muscle tone, hypersensitivity. }\end{array}$ & $\begin{array}{l}\text { Neocortical } \\
\text { regions }\end{array}$ & {$[46,253,254]$} \\
\hline $\begin{array}{l}\text { Parkinson's } \\
\text { Disease }\end{array}$ & $\begin{array}{l}\text { Bradykinesia, increased muscle tone, tremors, fine } \\
\text { motor control deficits, balance and gait impairments, } \\
\text { speech deficits, visuospatial deficits. }\end{array}$ & $\begin{array}{l}\text { Motor cortex, } \\
\text { cerebellum }\end{array}$ & {$[255-258]$} \\
\hline Rett Syndrome & $\begin{array}{l}\text { Cognitive impairment, speech impairments, loss of } \\
\text { movement and coordination, seizures, breathing } \\
\text { disturbances. }\end{array}$ & $\begin{array}{l}\text { Motor cortex, } \\
\text { cortical regions }\end{array}$ & [259-262] \\
\hline Spinal cord injury & Enhanced pain transmission, neuropathic pain. & Spinal cord & {$[263]$} \\
\hline $\begin{array}{l}\text { Traumatic brain } \\
\text { injury }\end{array}$ & $\begin{array}{l}\text { Cognitive impairment, attention, memory and executive } \\
\text { function deficits, speech impairments, speech deficits, } \\
\text { loss of consciousness, sleep disorders, loss of balance } \\
\text { and coordination, seizures. }\end{array}$ & $\begin{array}{l}\text { Variable, } \\
\text { depending on } \\
\text { site of trauma }\end{array}$ & [264-266] \\
\hline
\end{tabular}

neurotransmitters [3]. While NH has been generally associated with epilepsy and the development of seizures, it also occurs in many other neurological disorders (Table 1), indicating a strong relationship between hyperexcitability and brain dysfunction. While hyperexcitability across all these disorders is unlikely to share the same etiology, the presence of hyperexcitability in these disorders implies a more mechanistic role through which associated behavioral and cognitive symptoms can manifest.

Alzheimer's disease (AD) is a progressive neurodegenerative disorder without effective treatment at present. Current symptomatic treatment options for $\mathrm{AD}$ partially alleviate cognitive and physiological deficits, but do not significantly alter the pathology progression or prolong the lifespan of the patient [4]. The current, repeated failures of clinical trials serve to underscore the complex, multifactorial nature of $\mathrm{AD}$, indicating an incomplete understanding of the pathological mechanisms underlying this progressive disease [5]. These failures have been ascribed to reasons such as the validity of the available animal models, the validity of the tests for translational assays, the subjectivity of (early) clinical diagnoses as well as the lack of valid and precise biomarkers, e.g., for patient selection in clinical trials [5, 6]. The timing of therapeutic intervention has also been highlighted as a key factor influencing ineffectiveness in clinical trials [7], due to the extensive neurodegeneration likely present at the point of a confirmed diagnosis. Following this line of thinking, attention has turned to finding newer and more valid biomarkers of $\mathrm{AD}$ that allow for therapeutic intervention at an earlier stage of the disease, potentially allowing for halting or slowing of the disease [8].

Currently, the most accepted pathological features of $\mathrm{AD}$ are the presence of extracellular amyloid plaques and intracellular neurofibrillary tangles [9], chronic neuroinflammation [10], and neurodegeneration [11]. In addition to the molecular characteristics of $\mathrm{AD}$, neurophysiological characteristics of increased network activity [13], epileptic activity [14], slowing of neural oscillations [15] and reductions in waveform complexity [16] have also been reported in some patients.

Several observations point to NH in patients with $\mathrm{AD}$, even before incipient pathology, suggesting that hyperexcitability may be a prodromal feature of $\mathrm{AD}$ [17]. Consistent with these findings, indications of $\mathrm{NH}$ have been noted in animal models of pathology 
associated with AD [18-20]. Therefore, NH has been posited as a potential indication of dysfunctional neural networks thought to occur in the prodromal stages of $\mathrm{AD}$, linked to soluble amyloid- $\beta$ species and accumulating AD-related proteins and peptides [21], with links to cognitive dysfunction [22] and progression of pathology [23]. Here, we discuss the consequences of $\mathrm{NH}$ on network function, assess the evidence for $\mathrm{NH}$ in animal models and human patients, as well as address some of the gaps pertaining to the hypothesis of hyperexcitability in AD. Lastly, we provide a perspective on the development of animal models that proposes the application of $\mathrm{NH}$ as a measure of construct validity, as well as approaches to improve experimental design by incorporating the assessment of $\mathrm{NH}$ that are crucial for adequate translational validity.

\section{Implications of altered excitability for network function}

It has been established that the proper functioning of neurons is necessary for the development and the continued survival of the organism, as shown by the debilitating phenotypes associated with perturbances to neuronal function [24-26]. Neuronal excitability is one such property that governs a broad range of neuronal functions, ranging from, but not limited to: neuronal development, functional integration, and even cell death $[27,28]$. The factors that determine the excitability of a neuron arise from elements related to the generation of action potentials and can be broadly classified into factors intrinsic and extrinsic to the neuron. Intrinsic factors such as the density of receptors at a synapse, the properties of ion channels, or the phosphorylation state of certain proteins in the cell can all affect the excitability of a neuron [29]. For example, a mutation in voltage-gated sodium channels that results in the reduction of the sodium channel voltage activation threshold, subsequently requiring less depolarization to open the ion channel and initiate an action potential, could increase neuronal excitability [1]. Factors extrinsic to the neuron affecting its excitability would be associated with other determinants such as interactions with other inhibitory or excitatory neurons, the availability of extracellular neurotransmitters, the concentrations of surrounding extracellular ions, the presence of extracellular ligands which alter the membrane potential [29], or neuroinflammation [30]. An example of such an extrinsic factor would be inhibitory interneurons [2].

\section{Functional organization and network hyperexcitability-associated perturbations}

The activity of a neuron does not only depend on its excitability but also on the activity of other neurons to which it is connected within the network. One of the properties that emerges from the complex interaction of neurons in networks is neural oscillations, the high amplitude oscillations detectable from local extracellular field potentials to scalp recordings [31]. The intrinsically complex dynamics of single neurons that allow them to resonate and oscillate at multiple frequencies are a key feature believed to facilitate the emergence of large-scale oscillations that span multiple brain regions [32]. Neuronal oscillations have been classified into various bands in the frequency range from 0.05 to $500 \mathrm{~Hz}$, with different functional or behavioral correlates putatively ascribed to each of the frequency bands. However, definitions of the frequency bands may somewhat differ between researchers and between species investigated (e.g., [31, 33-35], the frequency bands of delta $(<4 \mathrm{~Hz})$, theta $(4-8 \mathrm{~Hz})$, alpha $(8-15 \mathrm{~Hz})$, beta $(16-31 \mathrm{~Hz})$, gamma $(>30 \mathrm{~Hz})$ ).

At the cellular level, the interaction between excitatory and inhibitory neuronal activity is known to be responsible for the generation of synchronous rhythms [36, 37]. Alterations in oscillatory rhythms have been implicated in some of the neurological disorders that exhibit hyperexcitability, such as epilepsy [38-40], AD [41-43], and Fragile X syndrome [44-46] as well as Parkinson's disease [47].

However, the relationship between different forms of hyperexcitability and the development of abnormal neuronal rhythms remains to be fully understood. One study observed marked increases in gamma band power and decreased phase-locking properties in patients with fragile $\mathrm{X}$ syndrome, which appears to be related to the observation of hyperexcitability [48]. $\mathrm{NH}$ has also been shown to be linked to the development of high-frequency oscillations $(80-500 \mathrm{~Hz})$, a potential biomarker of epilepsy [38, 49], with the presence of hyperexcitable mechanisms linked to these oscillations [50].

In the context of $\mathrm{AD}$, a multitude of oscillatory changes have been documented in the literature [51]. Indications of altered gamma activity [52-55] and slow-wave activity in animal models [56] are just some examples that have been reported. In AD patients, reports of altered theta, delta oscillation power [57], gamma, delta, and alpha power and amplitudes [58-60] in resting-state EEG as well as a 
"slowing" of oscillations [16] have been reported. However, studies exploring the potential causal link(s) between altered oscillatory activity and $\mathrm{NH}$ in $\mathrm{AD}$ are sparse $[53,61]$.

Another way in which NH may have large-scale implications is in terms of structural changes that may impact the function of the network. An important structural change associated with the development of seizures and epilepsy associated with the temporal lobe is the axonal sprouting of mossy fibers in the hippocampus [62]. Mossy fibers are the excitatory outputs of granule cells in the hippocampus, and the main excitatory output of granule cell layer, projecting toward the Cornu Ammonis region 3 in the hippocampus under physiologically normal conditions [63]. In response to injury and/or damage, as in repeated seizures, the mossy fibers of the granule cells redirect to the supragranular layer of the dentate gyrus [62]. Depending on the projections of this redirection toward the dendrites of other granule cells, or inhibitory interneurons, the resulting net effect on the hippocampal network could be excitatory or inhibitory, respectively [62, 64-67]. Therefore, this resulting structural change could further alter the balance of excitation and inhibition.

Considering the wide range of disturbances and brain disorders associated with $\mathrm{NH}$ as well as the structural and functional implications briefly covered above, the therapeutic management of this phenomenon in neurological disorders could modify the course of the disease or even contribute to recovery. Recently, NH has emerged as a potential neurophysiological readout of network dysfunction in AD and prognostic indicator of disease. However, what is the evidence that $\mathrm{NH}$ is a key feature of $\mathrm{AD}$ ? In the next section, the evidence for $\mathrm{NH}$ as a neurophysiological indicator of $\mathrm{AD}$ is reviewed and evaluated.

\section{NETWORK HYPEREXCITABILITY IN AD PATIENTS}

In humans, direct evidence for $\mathrm{NH}$ in patients with $\mathrm{AD}$ is sparse, due to ethical and practical considerations that would preclude a definitive evaluation of NH. Such a definitive evaluation would theoretically consist of exact placement of invasive recording electrodes or advanced magnetoencephalography (MEG) approaches, which are presently limited. Numerous other indirect indications suggest the existence of $\mathrm{NH}$ in patients with $\mathrm{AD}$, such as the presence of hippocampal hyperactivity [22, 68, 69], cortical hyperexcitability measured by transcranial mag- netic stimulation [70], increased risk of seizure and epileptic-like symptoms [14], and alterations in default mode network (DMN) inactivation [71, 72]. These alterations in brain function have been noted in subjects through techniques such as functional magnetic resonance imaging (fMRI) [13, 22], MEG [15], and transcranial magnetic stimulation (TMS) studies [73]. In this section, we discuss the past and recent observations supporting the presence of hyperexcitability in humans.

\section{Hippocampal hyperactivity}

Hippocampal hyperactivity is an important feature of $\mathrm{AD}$ during the prodromal stages of the disease [69, 74-76] and may reflect an observable manifestation of underlying $\mathrm{NH}$ in the early stages of the disease. The temporal progression of hippocampal activity has been reported to be increased during amnestic mild cognitive impairment (aMCI) and the preclinical phase of early $A D$ and progresses to reduced activity relative to baseline in the later phases of $\mathrm{AD}[71$, 77], when the diagnosis is confirmed. This observation of hippocampal hyperactivity has gained interest as a potential biomarker and functional indicator of the disease state for the development of therapeutic interventions [22, 78], and that may help to disentangle the multiple AD genotypes and phenotypes and their heterogeneous underlying clinicopathology. The evaluation of hippocampal hyperactivity has been carried out using various modalities such as fMRI, MEG, or positron emission tomography (PET). One such PET study has reported an increase in hippocampal glucose metabolism, where globalhippocampal connectivity decreases resulted in increased intrahippocampal glucose metabolism [79]. The increased glucose metabolism has been suggested to imply an increase in intrahippocampal activity, providing some evidence for the presence of hippocampal hyperactivity as well.

Hippocampal hyperactivity was initially proposed as a compensatory mechanism to support memory function [80] and has also subsequently been suggested to be maladaptive instead [22, 68, 81]. One study supporting the idea of a compensatory function examined blood oxygenation level brain response in nondemented participants with or without the apolipoprotein $\mathrm{E}(A P O E) \varepsilon 4$ allele, a major risk factor for the development of $\mathrm{AD}$ [80]. Blood oxygen level dependent (BOLD) activity levels in APOE $\varepsilon 4$ subjects were increased to a greater extent during learning of new images compared to control subjects, 
distributed in the precuneus, frontal, temporal, and cingulate gyri regions of the brain. This increase in activation during the learning task has been interpreted as a compensatory increase in cognitive effort to achieve comparable levels of episodic memory encoding.

Opposing this compensatory activation hypothesis, a study by Bakker and colleagues showed an improvement in cognitive function by reducing hyperactivity of the hippocampus using levetiracetam [22]. This reduced hippocampal activity was observed through fMRI readouts. The rationale proposed by Bakker and colleagues was that if hyperactivation was indeed beneficially compensatory, attenuation of hyperactivation would result in a reduction in cognitive function. However, the reduction of hyperactivity resulted in an improvement in cognitive function, suggesting that this hyperactivity was detrimental to cognitive function instead of a beneficial compensation.

These studies illustrate a seemingly dichotomous relationship between compensation and maladaptive phenomena in terms of hippocampal hyperactivity. While the words "compensatory" and "maladaptive" may initially appear to be mutually exclusive and dichotomous, it is possible compensatory mechanisms may lead to the development of detrimental states, such as in the case of maladaptive plasticity [82]. While it is not certain that the increased hippocampal activity reflects a compensatory or maladaptive state, it bears noting that these two concepts are not mutually exclusive.

There is an ongoing debate regarding the cause and timing of this hippocampal hyperactivity, with indications that implicate both amyloid and tau pathology as some of the responsible factors involved. PET has been employed to detect the pathology of amyloid plaques and more recently, the pathology of tau as well [83]. Prior to the application of PET scanning as a measure of the amount of amyloid and tau pathology, the extent of the pathology could only be quantified in postmortem tissue, precluding any definitive correlation between pathological load, hippocampal activity, and cognitive function while the patient was alive. Several studies have applied PET in conjunction with fMRI readouts to estimate the contribution of AD pathology to hippocampal hyperactivity [84-86]. Several studies carried out investigating the effects of amyloid- $\beta$ using PET imaging have reported both contrary increases [85, 87, 88] and decreases in brain activation [84, 89]. A recent article proposed that tau accumulation was associated with hippocampal hyperactivity, as opposed to amyloid- $\beta$ [86]. In this study, it was proposed that the emergence of hyperactivity occurs in the later stages of preclinical AD and leads to discrepancies in the correlation between amyloid- $\beta$ levels and hippocampal hyperactivity.

\section{Default mode network alterations}

Another observation that could also be related to underlying hyperexcitability is the deficiencies observed in the DMN of AD patients [90,91].

The DMN is an inter-regional brain network believed to be associated with introspective thinking, planning, and remembering the past [92]. The regions that comprise the $\mathrm{DMN}$ are the posterior cingulate cortex, precuneus, dorsal and ventral medial prefrontal, lateral (mainly inferior) parietal cortices, and medial temporal lobes [90]. DMN network activity is characterized by a consistent reduction in activity while performing goal-directed tasks and is activated during states of quiet rest [92]. Based on this characteristic of the DMN, one could conceptualize the deactivation and activation of the DMN as states of externally-directed focus and internally-directed thinking respectively [93]. It is believed that the proper activation and deactivation of the DMN is necessary for the retrieval of stored memories as well as the encoding and acquisition of new memories [94, 95]. Studies have shown that lower DMN activity during stimulus-driven goal-directed cognitive tasks is associated with more successful performance [96-98].

In the context of $\mathrm{AD}$, the $\mathrm{DMN}$ has been characterized by reductions in resting state functional connectivity and activity $[13,72,99-101]$ and is associated with the progression and severity of the disease [102-104]. In addition, the compromised integrity of the DMN system has been related to the progression of the disease $[102,103]$. In the context of taskrelated DMN activation, decreased levels of DMN task-related deactivation in $\mathrm{aMCI}$ and $\mathrm{AD}$ patients, as well as APOE4 carriers [71, 72, 105, 106] have been reported. However, in contrast to the decreased resting state functional connectivity, other studies have shown increased levels of functional connectivity, suggested to be compensatory $[99,104,107]$. One study has reported disrupted medial-parietal and medial-temporal lobe dysconnectivity has resulted in increased intrinsic medial-temporal lobe local functional connectivity [108] and subsequent increase in intrinsic activity. 
While evidence points toward an overall decrease in DMN functional connectivity and activity, especially in the later stages of the disease [71], a possible indication whereby hyperexcitability may exist is the decreased deactivation of the DMN. The decreased DMN deactivation indicates a possible inability to properly deactivate DMN or inappropriate DMN activation during these tasks $[91,106]$. $\mathrm{NH}$ could be one such mechanism that may explain the inability to appropriately deactivate the DMN which has been ascribed to the deficits associated with levels of GABA [109], suggesting that inhibitory deficits could be contributing to the reduced deactivation, and indicate a shift toward a more excitable network state. This decrease in deactivation has also been associated with the presence of amyloid pathology [110]. It is not clear if this reduced deactivation reflects a maladaptive mechanism, functional reorganization to reflect compensatory mechanisms in order to sustain cognitive functions, or both. Lastly, a link between alterations in the DMN and depression, a common comorbidity in AD has been suggested [111, 112], including ruminations-related electroencephalography (EEG) changes [113], which emphasizes the potential clinical importance of hyperexcitability beyond epilepsy per se.

These observations of decreased DMN deactivation might reflect underlying hyperexcitability in the earlier stages of the disease [72, 105]. However, it also bears noting that multiple reports have indicated overall DMN activity reduction [71]. A better understanding of how decreased DMN deactivation might be related to $\mathrm{NH}$ could provide a better insight into translational indications of AD or eventually even of $\mathrm{AD}$ patient stratification.

\section{Cortical hyperexcitability}

Another form of hyperexcitability suggested comes from studies involving TMS of the motor cortex in patients with $\mathrm{AD}[70,73,114,115]$. These studies involve the stimulation of the motor cortex using a TMS paradigm and measurement of the evoked motor potential. The minimum stimulation threshold necessary to evoke a motor threshold in $\mathrm{AD}$ patients has been reported to be lower than that healthy controls, suggesting an "increased" motor cortex excitability [114]. This increased excitability of the motor cortex is suggested to be a compensatory mechanism to facilitate voluntary movements [70]. Current discussion has attributed this alteration in excitability to dysfunction of cholinergic and glutamatergic signaling [70].

There is evidence for the deterioration of the cholinergic signaling system in AD throughout the disease, generally stemming from the neurodegeneration of cholinergic neurons in the Nucleus basalis of Meynert, in the basal forebrain [116]. This region harbors neurons rich in the acetylcholine neurotransmitter and projects extensively into cortical regions (for a review of the cholinergic system, see Mesulam, 2013 [117]). The motor cortex has muscarinic and cholinergic terminals and receives a large input from the Nucleus basalis of Meynert [118], believed to be inhibitory $[119,120]$. The neurodegeneration of these cholinergic neurons in $\mathrm{AD}$ would lead to a reduction in inhibition based on this hypothesis and could contribute to cortical hyperexcitability.

\section{Risk of seizures and epilepsy}

Epilepsy is considered to be strongly related to $\mathrm{NH}$, with its myriad of etiology generally ascribed to the imbalance of excitation and inhibition and the development and onset of seizures [121].

Patients with AD have been reported to have an increased risk of developing seizures over the course of the disease $[14,122]$. The prevalence of seizures appears to increase with the duration of $\mathrm{AD}$, with studies correlating onset of seizures with the later stages of AD [123-125]. This observation has been hypothesized to be due to the progressive severity of neurodegeneration or the increased accuracy of the diagnosis of $\mathrm{AD}$ [122]. Other studies have observed an increased rate of seizure occurrence in younger patients with $\mathrm{AD}[126,127]$, attributed to the higher prevalence of patients with familial $\mathrm{AD}$, which has been associated with higher rates of seizures or more aggressive progression of $\mathrm{AD}$ [122].

Seizures are believed to arise from the hypersynchronous state of neuronal populations, characterized by heterogeneity of neuronal firing and temporal evolution of synchronization [128]. Physiological evidence for abnormal neuronal synchronicity has been reported in animal models of AD pathology $[18,20,129,130]$, highlighting a possible mechanistic explanation for epileptogenesis in patients with AD. Although the clear causative factor underlying the development of seizure-like activity in AD is not fully understood, animal studies have attributed the presence of amyloid and tau pathology, as well as interneuron dysfunction to epileptogenesis. Due to 
the difficulty of detecting seizures, particularly of the nonconvulsive form, characterizing the prevalence of seizures in patients with prodromal AD is extremely challenging [131]. It is not clear which form(s) of epilepsy is (are) engendered in AD or if it can be classified into a single type. Due to the numerous forms of epilepsies, the presence of epilepsy-like and seizure-like symptoms in AD patients may even differ from hitherto known forms of epilepsy such as temporal lobe epilepsy. Studies investigating the types of seizures in patients with $\mathrm{AD}$ have reported generalized convulsive seizures [132], complex partial seizures [133], as well as nonconvulsive seizures [131], indicating some extent of seizure heterogeneity in patients with $\mathrm{AD}$. Other indications point to similarities between the seizure activity observed in patients with $\mathrm{AD}$ and those with focal hippocampal seizures [14]. However, certain limitations and inaccuracies in seizure reporting could also preclude an accurate assessment of seizure prevalence in $\mathrm{AD}$ patients [134].

Correlational studies have shown that the incidence of seizure activity in patients with $\mathrm{AD}$ is related to faster cognitive decline compared to $\mathrm{AD}$ patients with no reported incidence of seizures [135]. One possibility suggests that the severity of the pathology may determine the rate of seizure prevalence. Another possibility suggests that the presence of seizures could exacerbate the rate of disease progression. Better characterization of epilepsy and seizure phenotypes in patients with $\mathrm{AD}$ could provide a better insight into how epilepsy-associated phenomena contribute to $\mathrm{AD}$ pathogenesis or even serve as a predictive indicator of disease progression for therapeutic intervention (for a recent review see Toniolo et al. [77]). In their first retrospective studies by Vossel et al. examining the incidence of seizures in $233 \mathrm{MCI}$ subjects and 1,024 probable AD subjects, the incidence rate of repeated seizures in MCI and probable AD patients was $5 \%$ and $3.4 \%$ respectively [136], while in their prospective follow-up study, this prevalence rate reached $42 \%$ in patients with $\mathrm{AD}$ [137]. This indicates that not all patients develop seizures, suggesting an incomplete penetrance of this phenotype, and that $\mathrm{NH}$ in the form of seizures may potentially only be present in a subpopulation of AD patients, emphasizing the heterogeneity of the AD patient population [21].

The presence of increased network activity and the prevalence of epileptiform activity in patients with AD suggests hyperexcitability occurring throughout the disease. Although the full spectrum of molecular and cellular correlates of NH has not been elucidated, several reports have identified factors leading to the development of NH. In the next section, we review some of the putative pathological mechanisms of $\mathrm{NH}$ from studies primarily conducted in animals.

\section{PRECLINICAL STUDIES OF AD-RELATED NETWORK HYPEREXCITABILITY}

Evidence in $\mathrm{AD}$ patients points toward the possibility of $\mathrm{NH}$, most likely correlating with increased activation of several regions of the brain, such as the DMN and the hippocampus. However, the determination of molecular pathological correlates as well as the localization of hyperexcitability directly in humans would require some form of invasive electrode implantation for measurement of electrophysiological changes associated with hyperexcitability. This has led to studies attempting to elucidate the molecular and cellular correlates of $\mathrm{NH}$ in animal models exhibiting AD-associated pathology. It should be noted that differences in techniques used for the experimental qualification of hyperexcitability in humans as compared to in animal models, could preclude a direct translational comparison. In this regard, it is possible that the exact nature of hyperexcitability in animal models may differ from that in human patients.

Unlike techniques used in human studies to evaluate neurophysiology, preclinical studies of hyperexcitability involve techniques such as intracranial EEG [19, 52], calcium imaging [129, 138], and patch clamping of ex vivo slices [18, 139] carried out in animal models of AD pathology. Hence, a closer look at animal studies associated with the incipience of $\mathrm{NH}$, as well as a critical evaluation of the evidence for the pathological bases of $\mathrm{NH}$ will be presented next.

\section{Glutamate dysfunction as a molecular mechanism underlying network hyperexcitability}

The glutamate hypothesis of $\mathrm{AD}$, initially proposed decades ago, was based on postmortem evidence indicating reduced aspartate binding as well as a loss of other putative markers of glutamatergic activity [140]. The observation of increased glutamate concentrations around neurons and synapses, attributed to deficits in the glutamatergic processing pathway is at the heart of this hypothesis [141]. Glutamate, being the main excitatory neurotransmitter in the brain, could be a main molecular effector of inducing $\mathrm{NH}$. 
Glutamate receptors can be classified into ionotropic and metabotropic glutamate receptors, both of which have been suggested to be implicated in hyperexcitability and excitotoxicity $[142,143]$. Of the two groups, metabotropic glutamate receptors (mGluRs) have been shown to interact with AD pathology, such as extracellular oligomeric amyloid- $\beta$ species, resulting in LTD induction [144], synaptotoxicity [145], among other effects [146]. It has also been shown that the interaction of amyloid- $\beta$ with a particular mGluR subtype, mGlu1, results in a dramatic and lasting depolarization of membrane potential [147]. This depolarization could very likely contribute to a transition to a state of hyperexcitability. However, the activation of mGlu1 has also been associated with the proteolytic processing of amyloid- $\beta$ protein precursor (A $\beta P P)$, increasing the production of the neuroprotective sA $\beta P P \alpha$ fragment, and a decrease in amyloid- $\beta$ production [148], potentially serving as a sensor of extracellular amyloid- $\beta$ levels. In vitro application of amyloid- $\beta$ fragments in slice culture have shown increased glutamate concentrations [149], potentially through augmenting glutamate release [150] or by inhibiting the uptake of glutamate by astrocytes [151, 152]. A recent in vivo report also appears to be in line with the in vitro findings, reporting increased neuronal activity being attributed to glutamate accumulation as a result of amyloid- $\beta$ [143].

The role of glutamate has also been implicated in the process of glutamate-mediated excitotoxicity, the process by which neurons succumb to damage or die as a result of overstimulation by glutamate [153]. It has been suggested that the neurodegeneration seen in $\mathrm{AD}$ could be the result of this form of excitotoxicity $[153,154]$. This excitotoxicity is believed to be mediated by an increased influx of calcium, primarily through NMDA receptors $[155,156]$. The hyperexcitability seen in AD could also imply ensuing excitotoxicity.

\section{Inhibitory signaling dysfunction as a cellular basis of network hyperexcitability}

Based on the hyperexcitability model resulting from an excitation and inhibition imbalance, inhibitory signaling represents a major player in this balance. Inhibitory signaling is a product of both the inhibitory presynaptic neuron and receptors on the postsynaptic neuron. Interneurons are a major source of inhibitory input to neurons, generally facilitated by the action of neurotransmitters such as the GABA neurotransmitter [157].
Several indications of interneuron dysfunction appear to be present in $\mathrm{AD}$, primarily from preclinical studies $[52,53,158]$ but have yet to be well studied and characterized in human observations. These preclinical studies identified alterations suggested to be attributed to parvalbumin-expressing cells [52] and hippocampal perisomatic GABAergic synapses [159]. In addition, the restoration of these interneuron cell populations appears to attenuate effects of hyperexcitability [160] as well as the restoration of deficits in oscillatory brain rhythms [53].

Neurophysiological changes in interneurons associated with AD pathology appear to be evident in multiple mouse models of AD pathology, with functional implications for the network $[52,53]$. One of these functional consequences concerns the alteration of oscillatory rhythms. Interneuron activity contributes greatly to the presence of gamma oscillations in the brain [161], and are believed to contribute to the temporal coordination of neuronal activity at the network level, facilitating aspects of cognition and neuronal computation [162-164]. Along with putative changes in interneurons, the properties of gamma oscillations have also been noted to be altered in several mouse models of AD pathology $[54,165,166]$, correlating the neurophysiological changes with functional changes.

Although some direct evidence for the presence of interneuron deficits in $\mathrm{AD}$ patients is present [52], indirect evidence also supports this hypothesis. Oscillatory activity is impaired in patients with $\mathrm{AD}$, in particular gamma oscillations [167-169]. A recent study involving the application of light stimulation at the gamma frequency range to entrain interneurons has been reported to clear amyloid plaque build-up [170], suggesting that external neuromodulation of interneuron function may be capable of altering pathology.

In addition to changes in oscillatory activity, interneuron deficits have also been correlated with the presence of epileptic and seizure phenomenon $[171,172]$. One such study has reported reductions in network hypersynchrony facilitated by modified interneuron transplants in a mouse model of $\mathrm{AD}$ pathology [53]. While network synchrony was shown to be reduced in this study, it should be noted that it does not imply that interneuron dysfunction might not be the cause of this of form of hypersynchrony but instead only attenuates it.

Interneuron deficits present itself as a potential cellular candidate for explaining the presence of $\mathrm{NH}$ in animal models and patients with AD. Expanding 
our understanding of interneuron deficits (e.g., subtypes of interneuron affected, receptor expression properties, interneuron quantity) should provide better insight into the development of animal model on a cellular basis of $\mathrm{NH}$.

\section{Amyloid-associated network hyperexcitability in animal studies}

Several animal models of amyloid pathology showcase hyperexcitability-related behavior in the form of their propensity to exhibit unprovoked seizures [19], increased susceptibility to pharmacologically [173] and audiogenic seizures [18] as well as epileptiform-like activity [130, 174]. This effect also does not appear to be limited to a single amyloid animal model but appears to be a common trait across multiple amyloid pathology models [18, 173-175], indicating a phenotype strongly associated with amyloid-related alterations in these mice. Studies associated with $\mathrm{NH}$ and amyloid are summarized in Table 2.

The hyperexcitability associated with amyloid- $\beta$ also appears to be dose-dependent, as suggested by the presence of tonic-hyperexcitability proportionate to the amount of amyloid plaque burden [138, 176]. However, it has been suggested that the molecular correlate of this hyperexcitability is likely to be the oligomeric species of amyloid- $\beta$ [143], rather than the amyloid plaques as suggested by experiments involving ex vivo application of amyloid- $\beta$ species described in the following section.

Ex vivo experiments involving the application and incubation of amyloid- $\beta$ species have demonstrated that these oligomeric species possess the ability to depolarize the membrane potential and shift the network to a more excitable state $[19,177]$. However, the excitability of the network already appears to be permanently altered as evidenced by ex vivo slice experiments on these mouse models of amyloid pathology $[18,178]$. This suggests the possibility that chronic exposure of neurons to extracellular amyloid- $\beta$ could already induce permanent changes in the network, providing a possible explanation for the lack of clear effects seen in amyloid clearancerelated therapies. Alternatively, the development of the organism could be altered under the influence of the transgenic expression of proteins responsible for $\mathrm{AD}$ pathology, resulting in an already abnormal baseline state.

Accompanying the ex vivo experiments involving the application of amyloid- $\beta$ to brain slices, one in vivo experiment involving the application of amyloid species appear to elicit similar results as visualized by calcium imaging [143]. Paradoxically, this only had an effect when amyloid- $\beta$ was applied in wild-type mice as opposed to mice with amyloid phenotypes. This suggests some sort of alteration of the network already present in response to the presence of transgenic manipulations associated with amyloid.

Neuronal activity has also been shown to affect A $\beta P P$ processing and the release of amyloid- $\beta$ species $[23,179]$. It is suggested that the increase in neuronal activity leads to an increase in amyloid- $\beta$ secretion and aggregation into oligomers which could be part of a positive feedback loop driving each other reciprocally.

The functional consequences of amyloid-associated hyperexcitability still lacks sufficient understanding. Apart from the suggested role of amyloid- $\beta$ associated hyperexcitability prompting subsequent epileptogenesis [19], in a functional context, one other study has reported that progressive deterioration of neuronal tuning for visual stimuli occurs in relation to amyloid load. In particular, this was noted only in hyperactive neurons during spontaneous activity [180]. In the context of amyloid- $\beta$ associated hyperexcitability and its purported role in excitotoxicity [181], animal models bearing amyloidassociated transgenic manipulations generally do not show overt neurodegeneration or cell loss [182], even in the presence of high amounts of amyloid plaque load and seizures. This implies that neurodegeneration in $\mathrm{AD}$ may not be linked solely to the presence of amyloid-driven hyperexcitability and excitotoxicity. However, amyloid-associated hyperexcitability may indirectly facilitate the development of amyloid plaques, which may drive the propagation of tau pathology and subsequent tau-pathology-associated neurodegeneration [23, 179, 183]. Moreover, specific proteins and AD-related peptides (e.g., sA $\beta \mathrm{PP} \alpha$ or $\mathrm{A} \eta$ ) are increasingly being identified for their specific role in circuit excitability dynamics, hypothesizing the mediating effects of amyloid as well as tau to hyper- and hypoexcitability [21].

\section{Tau-associated network hyperexcitability in animal studies}

In addition to the studies of $\mathrm{NH}$ focusing on amyloid pathology in $\mathrm{AD}$, the other main hallmark of $\mathrm{AD}$, the tau protein, has been shown to be related to hyperexcitability [184-188]. Tau is a 
Table 2

Animal studies of amyloid-related hyperexcitability

\begin{tabular}{|c|c|}
\hline \multicolumn{2}{|l|}{ In vivo } \\
\hline Experimental paradigm & Animal model(s) \\
\hline \multirow[t]{3}{*}{$\begin{array}{l}\text { Two-photon calcium } \\
\text { imaging }\end{array}$} & APPswe/PS1G384A \\
\hline & $\begin{array}{l}\text { APPswe/PS1G384A } \\
\text { APPswe and } \\
\text { PS1G384A, PS45 } \\
\text { mice } \\
\text { APP23xPS45 mice } \\
\text { Wild-type mice }\end{array}$ \\
\hline & $\operatorname{Tg} 2576$ mice \\
\hline $\begin{array}{l}\text { Local field potential } \\
\text { stimulation and } \\
\text { recording under } \\
\text { urethane anesthesia }\end{array}$ & $\begin{array}{l}3 \times \mathrm{TgAD} \text { mouse } \\
\text { model }\end{array}$ \\
\hline $\begin{array}{l}\text { In vivo patch clamp and } \\
\text { local field potential } \\
\text { recordings under } \\
\text { isoflurane anesthesia }\end{array}$ & $\begin{array}{l}\text { APPswe/PS1dE9 } \\
\text { model }\end{array}$ \\
\hline Freely moving subdural & hAPPJ20, \\
\hline EEG recordings & $\begin{array}{l}\text { hAPPJ20xFVB/N } \\
\text { amyloid mouse } \\
\text { model } \\
\text { hAPP-J20 amyloid } \\
\text { mouse model } \\
\text { APP/TTA mice }\end{array}$ \\
\hline
\end{tabular}

Freely moving cortical screw EEG recordings

Freely moving epidural EEG recordings

Freely moving subcortical local field potential recordings

Seizure induction pharmacological /chemical
Main finding and conclusion

Reference

Early hyperactivity of hippocampal neurons in

[176]

predepositing transgenic mice.

Soluble $A \beta$ induces neuronal hyperactivity in wild-type mice.

Neuronal hyperactivity in absence of plaque or neuroinflammation pathology.

Hyperactivity of cortical neurons is significantly enhanced by AD-related mutations in presenilins. Hyperactive neurons found near amyloid plaques. Application of soluble synthetic $A \beta$ induced a massive increase in activity.

Anti-A $\beta$ antibody 3D6 reduces amyloid pathology but increases neuronal hyperactivity.

Increased synaptic facilitation in the $3 \times \mathrm{TgAD}$ model.

Significant differences in fEPSP amplitudes generated in 17-18 months of age 3xTgAD mice. Hyperexcitability on the cellular and network levels in APP/PS1 mice in vivo.

Network hypersynchrony emerges during reduced gamma activity in hAPPJ 20 mice.

Presence of epileptiform spike activity in hAPPJ20 mice.

Hyperexcitability and unprovoked nonconvulsive seizure activity in hAPP-J20 mice.

Overproduction of $A \beta$ is not sufficient to generate EEG abnormalities in double knock-in APP/PS1 mice.

$\mathrm{A} \beta \mathrm{PP}$ overexpression alters the excitatory to inhibitory balance in the cortex.

Suppression of AßPP overexpression during postnatal development delays the onset of EEG abnormalities in APP/TTA mice.

hAPP J20, APP-KI_ ${ }^{\text {NL-F }}$ mice

APPswe/PS1dE9 amyloid model $\operatorname{Tg} 2576$ mouse model

hAPP-I5,

hAPP-J20, APP $\mathrm{NL}-\mathrm{G}-\mathrm{F}$ Tg2576 mouse model

J20 mice exhibit frequent inter-ictal spikes but $\mathrm{APP}^{\mathrm{NL} / \mathrm{F}}$ mice do not.

Increased prevalence of unprovoked seizures based on video-EEG recordings.

Tg2576 mice exhibit spontaneous epileptiform activity as young as 1.5 months of age.

Non-convulsive epileptiform activity present across all mice.

Interictal-like spikes are present in 5-week-old Tg2576 mice during REM sleep.

Interictal-like spikes increase with age and emerge in additional behavioral states besides REM sleep.

$\operatorname{Tg} 2576$ mouse model

$\operatorname{Tg} 2576$ mice show higher susceptibility to pharmacologically induced seizures from early age.

hAPP-J20, J9, ARC48, I5, N8, Increased seizure activity after PTZ administration in hAPP-J20 mice.

J9/FYN, hAPP-J20/Tau-/amyloid mouse models 
Table 2

(Continued)

\begin{tabular}{|c|c|c|c|}
\hline \multicolumn{4}{|l|}{ In vivo } \\
\hline Experimental paradigm & Animal model(s) & Main finding and conclusion & Reference \\
\hline & APP/TTA mice & $\begin{array}{l}\text { Increased susceptibility to chemically induced } \\
\text { seizures is not attenuated by diminishing } \\
\text { spontaneous hyperactivity. }\end{array}$ & [215] \\
\hline $\begin{array}{l}\text { Seizure induction - } \\
\text { audiogenic }\end{array}$ & $\begin{array}{l}3 \times T g A D \text { mouse } \\
\text { model }\end{array}$ & $\begin{array}{l}\text { Young } 3 \times T g-A D \text { mice are highly susceptible to } \\
\text { audiogenic seizures. }\end{array}$ & [18] \\
\hline \multicolumn{4}{|l|}{ Ex vivo } \\
\hline \multirow[t]{3}{*}{$\begin{array}{l}\text { Brain-slice extracellular } \\
\text { field potential } \\
\text { recordings }\end{array}$} & $\begin{array}{l}\text { hAPP-J20, J9, } \\
\text { ARC48, I5, N8, } \\
\text { J9/FYN, } \\
\text { hAPP-J20/Tau-/- } \\
\text { amyloid mouse } \\
\text { models }\end{array}$ & $\begin{array}{l}\text { Increased inhibition in granule cells of hAPP-J } 20 \\
\text { mice. } \\
\text { Short- and long-term plasticity impairments in the } \\
\text { dentate gyrus of hAPP-J } 20 \text { mice }\end{array}$ & {$[20]$} \\
\hline & $\begin{array}{l}\text { APPswe/PS1dE9 } \\
\text { model }\end{array}$ & $\begin{array}{l}\text { Impaired short-term synaptic plasticity in aged } \\
\text { APdE9 mice. }\end{array}$ & {$[270]$} \\
\hline & $\begin{array}{l}\text { APPswe/PS1dE9 } \\
\text { model }\end{array}$ & $\begin{array}{l}\text { Age-dependent } \mathrm{A} \beta \text { relationship with membrane } \\
\text { depolarization that enhances the excitability of } \\
\text { pyramidal cells. }\end{array}$ & [19] \\
\hline \multirow[t]{6}{*}{$\begin{array}{l}\text { Whole-cell patch clamp } \\
\text { recordings }\end{array}$} & $\begin{array}{l}\text { APPswe/PS1dE9 } \\
\text { and WT mice }\end{array}$ & $\begin{array}{l}\text { Membrane depolarization was exclusively found } \\
\text { after application of (proto-)fibrillar A } \beta 1-42 \text { to } \\
\text { L2/3 pyramidal cells in cell-attached recordings } \\
\text { Short- and long-term plasticity impairments in the } \\
\text { dentate gyrus of hAPP-J } 20 \text { mice APdE9 mice } \\
\text { exhibited decreased action potential threshold and } \\
\text { burst firing of pyramidal cells. }\end{array}$ & [19] \\
\hline & $\begin{array}{l}\text { APPswe/PS1dE9 } \\
\text { model }\end{array}$ & $\begin{array}{l}\text { Decreased action potential generation probability of } \\
\text { interneurons in aged APdE9 mice. }\end{array}$ & [270] \\
\hline & Xenopus Laevis & $\begin{array}{l}\text { A } \beta \text { oligomers elicit inward currents in NR1/NR2A } \\
\text { and NR1/NR2B-injected Xenopus oocytes. }\end{array}$ & [139] \\
\hline & C57-BL6/J Mice & $\begin{array}{l}A \beta \text { treatment resulted in the hyperpolarization of the } \\
\text { action potential threshold. } \\
A \beta \text { treatment depressed the } \\
\text { after-hyperpolarization that followed action } \\
\text { potentials. }\end{array}$ & {$[177]$} \\
\hline & $\begin{array}{l}\text { APPswe/PS1dE9 } \\
\text { model }\end{array}$ & $\begin{array}{l}\text { Increased intrinsic excitability of CA1 pyramidal } \\
\text { neurons of APP/PS1 mice. }\end{array}$ & {$[178]$} \\
\hline & $\begin{array}{l}\text { hAPPJ } 20 \text {, } \\
\text { hAPPJ20xFVB/N } \\
\text { amyloid mouse } \\
\text { model }\end{array}$ & $\begin{array}{l}\text { Inhibitory synaptic impairments and parvalbumin } \\
\text { cell Dysfunction in hAPPJ } 20 \text { mice. }\end{array}$ & {$[52]$} \\
\hline $\begin{array}{l}\text { Intracellular current } \\
\text { clamp recording }\end{array}$ & $\begin{array}{l}3 \times T g A D \text { mouse } \\
\text { model }\end{array}$ & $\begin{array}{l}\text { Young } 3 \times T g-A D \text { mice exhibit hyperexcitability of } \\
\text { the hippocampal CA } 3 \text { neuronal network. } \\
\text { Spontaneous epileptiform discharges elicited by } \\
\text { the application of bicuculline on hippocampal } \\
\text { slices in } 3 \times T g-A D \text { mice. }\end{array}$ & {$[18]$} \\
\hline $\begin{array}{l}\text { Voltage-sensitive dye } \\
\text { imaging }\end{array}$ & $\begin{array}{l}\text { APPswe/PS1dE9 } \\
\text { model }\end{array}$ & $\begin{array}{l}\text { Hippocampal circuit hyperexcitability in the dentate } \\
\text { gyrus of APPswe/PS1dE9 mice. }\end{array}$ & {$[270]$} \\
\hline \multicolumn{4}{|l|}{ In vitro } \\
\hline Experimental paradigm & $\begin{array}{l}\text { Animal model }(\mathrm{s}) / \\
\text { In vitro model }(\mathrm{s})\end{array}$ & Main finding and conclusion & Reference \\
\hline $\begin{array}{l}\text { Primary neuronal cell } \\
\text { culture calcium } \\
\text { imaging }\end{array}$ & $\begin{array}{l}\text { Sprague-Dawley } \\
\text { rats }\end{array}$ & $\begin{array}{l}\mathrm{A} \beta \text { oligomers induce } \mathrm{Ca}^{2+} \text { influx into cortical } \\
\text { neurons in culture by activating preferably } \\
\text { NMDA receptors lacking NR2B subunit. }\end{array}$ & [139] \\
\hline $\begin{array}{l}\text { Cell culture } \\
\text { electrophysiological } \\
\text { recording }\end{array}$ & HEK293 cells & $\begin{array}{l}\text { Sodium currents are reduced in APP knockdown } \\
\text { HEK293 Nav1.6 cells. }\end{array}$ & {$[271]$} \\
\hline
\end{tabular}


microtubule-associated protein that is involved in the assembly or disassembly of microtubules [189].

Several reports have indicated that levels of tau modulate $\mathrm{NH}$, with reductions of endogenous tau protein levels ameliorating hyperexcitability [185, 190, 191] and overexpression exacerbating hyperexcitability [192, 193]. These findings suggest that levels of tau proportionately facilitate $\mathrm{NH}$.

Moreover, contrary evidence has suggested that increase in tau is capable of silencing neurons and contributing towards a state of reduced excitability [188, 194, 195]. A summary of reports involving tau-associated NH can be seen in Table 3. There may be several mechanisms by which tau dysfunction may elicit a phenotype of hyperexcitability or even the opposite. Activation of synaptic and extrasynaptic NMDA receptors has been shown to correlate with an increased expression of tau [196, 197]. In addition to this, at least one type of NMDAR activation, Fyn-mediated NMDAR activation, has been reported to be associated with tau [198]. As previously discussed, amyloid- $\beta$ has also been indicated to interact with NMDA receptors [139]. This relationship between amyloid- $\beta$, NMDAR interaction, and tau-mediated NMDA activation may be one mechanistic explanation for the presence of increased neuronal activation in AD. Another factor that may contribute to increased levels of tau expression could be increased levels of extracellular glutamate also interacting with $\alpha$-amino-3-hydroxy5-methyl-4-isoxazolepropionic acid (AMPA) and NMDA receptors [142, 199].

However, the effect of tau reduction in an animal model without amyloid-related mutations (e.g., in Kcna1+/-Tau+/-C57BL/6 mice) shows that the reduction of levels of tau results in the attenuation of hyperexcitability in this model [185]. This suggests that there may not be a preference of tau to a specific cause of hyperexcitability and that tau is a general regulator of intrinsic neuronal excitability and alters the excitation/inhibition balance without any particular preference for amyloid [200].

However, conflicting evidence for the effects of tau pathology on the effects of neuronal activity is present. One study reported the silencing of hyperactive neurons observed in amyloid-bearing APP/PS1 animals when crossed with inducible tau-expressing rTg4510 and rTg21221 mice [188]. These mice bear the mutated form of the human tau protein, the P301L mutation that confers a risk for developing frontotemporal dementia in humans [201]. This suggests that in this case, an increase in mutant tau expression could silence the increased activity associated with the APP/PS1 mouse strain as evaluated by calcium imaging.

In addition, other reports of mutated and soluble tau protein species has been shown to reduce the transient frequency of calcium in cortical neurons in layers $2 / 3$ of P301S mice, independent of neurofibrillary entanglement [194]. Moreover, the highfrequency ripple oscillations of local field potentials in the CA1 hippocampal area are considerably reduced in young $\mathrm{rTg} 4510$ mice, and even more deteriorated in old rTg4510 mice [195]. In addition, diminished neuronal activity with tau pathology in aged EC-tau mice [202], as well as reduced raw theta power in mice models of tauopathies [203], have been reported. One other study has suggest that entorhinal cortex neuronal hyperactivity is associated with the human amyloid precursor protein (hAPP) or $\mathrm{A} \beta$, instead of tau in a combined tau-amyloid mouse model [204]. These reports have indicated evidence for tau being capable of reducing neuronal activity and highlight a role in neuronal silencing.

The phosphorylation of tau, a main factor thought to lead up to the formation of neurofibrillary tangles, appears to exhibit a role in attenuating hyperexcitability as well. Several reports have shown that tau hyperphosphorylation is associated with reductions in hippocampal CA1 neuron excitability [205, 206] as well as decreased synaptic AMPA receptor expression due to mislocalization of tau as a result of hyperphosphorylation [207]. At least one study has suggested that phosphorylation of tau at a specific site is protective against amyloid- $\beta$ mediated excitotoxicity [187], suggesting that phosphorylation of tau may attenuate hyperexcitability. These findings suggest that phosphorylation of tau could be a possible response to hyperexcitability, in order to silence and counteract the increase in excitability [187, 208]. In contrast to the pathological role currently thought to be associated with tau, there appears to be some evidence indicating a beneficial or compensatory role for the existence of this mechanism, at least in the attenuation of hyperexcitability. Assuming this relationship between tau phosphorylation and NH holds true, increasing tau phosphorylation to counteract $\mathrm{NH}$ as a therapeutic strategy is unlikely to be a viable option due to the exacerbation of tau pathology and its associated detrimental effects.

These studies have highlighted some examples of how tau and tau-associated pathology may be related to NH. It does not appear to paint a clear picture whether tau contributes to or attenuates neuronal 
Table 3

Animal studies of tau-associated hyperexcitability

\section{In vivo}

\begin{tabular}{llll}
\hline $\begin{array}{l}\text { Experimental } \\
\text { paradigm }\end{array}$ & Animal model(s) & Main finding and conclusion & Reference \\
\hline
\end{tabular}

\section{Two-photon}

calcium

imaging

Anaesthetized

EEG

amperometry

Freely moving

subdural EEG

recordings

Freely moving subcortical EEG recordings

Seizure induction - pharmacologi$\mathrm{cal} / \mathrm{chemical}$

\author{
APP/PS1, Tg4510, \\ APP/PS1- \\ rTg4510, \\ APP/PS1- \\ rTg21221 \\ P301S mice
}

P301L mice

hAPP/Tau+/t,

hAPP/Tau+/-,

hAPP/Tau-/-,

TASD41/Fyn/Tau, SOD1G93A mice, amyloid-tau mouse models rTg4510

Kcna1 + /-Tau+/C57BL/6 mice

APP23/p38 $\gamma^{-/-}$
mice

EC-Tau mice

EC-Tau/hAPP mice

rTg4510 mice

hAPP/Tau+/+, hAPP/Tau+/-, hAPP/Tau-/amyloid-tau mouse models C57BL/6J

hAPP/Tau+/+, hAPP/Tau+/-, hAPP/Tau-/-, TASD41/Fyn/Tau, SOD1G93A mice, amyloid-tau mouse models hTau A152T
Tau-dependent suppression of activity and neuronal silencing.

[188]

Strong reduction of calcium transient frequency in layer $2 / 3$ cortical neurons of P301S mice, independent of neurofibrillary tangle presence.

The amplitude of KCl-evoked glutamate release was 4 and 7 times larger in TauP301L mice.

Tau reduction alters spontaneous epileptic activity from convulsive to nonconvulsive activity in hAPPJ9/Fyn mice.

Tau reduction prevents EEG abnormalities and spontaneous seizures in hAPPJ20 mice.

High-frequency ripple oscillations of local field potentials in the hippocampal CA1 area are significantly reduced in young rTg4510 mice, and even further deteriorated in old rTg4510 mice.

Decreasing tau reduces hyperexcitability and spontaneous seizures in Kv1.1-deficient mice.

Reducing tau phosphorylation via depletion of postsynaptic $\mathrm{p} 38 \gamma$ exacerbates excitotoxicity and deficits in APP transgenic mice.

Reduced grid cell firing and periodicity in the dorsal MEC of aged EC-Tau mice.

Tau has no impact on overall firing rate but diminishes the rate of narrow spiking single units in EC-Tau mice with amyloid. Diminished raw power and peak theta frequency in tau $\mathrm{Tg} 4510$ mice.

Tau attenuation results in seizure reduction induced by PTZ administration.

Reducing tau mRNA and protein protects against PTZ and PTX-induced seizures. Tau attenuation results in seizure reduction induced by PTZ administration in hAPPJ9/Fyn and hAPPJ20 mice.

The A152T variant enhances hTau-induced PTZ challenge. 
Table 3

(Continued)

\begin{tabular}{|c|c|c|c|}
\hline \multicolumn{4}{|l|}{ In vivo } \\
\hline $\begin{array}{l}\text { Experimental } \\
\text { paradigm }\end{array}$ & Animal model(s) & Main finding and conclusion & Reference \\
\hline $\begin{array}{l}\text { Seizure induction } \\
\text { - physical }\end{array}$ & $\begin{array}{l}\text { Drosophila } \\
\text { melanogaster } \\
(\text { eas, } k c c) \text { strains }\end{array}$ & $\begin{array}{l}\text { Reducing tau decreases hyperexcitability in } \\
\text { bang-sensitive Drosophila mutants. }\end{array}$ & {$[185]$} \\
\hline \multicolumn{4}{|l|}{ Ex vivo } \\
\hline \multirow[t]{3}{*}{$\begin{array}{l}\text { Slice extracellular } \\
\text { field potential } \\
\text { recordings }\end{array}$} & $\begin{array}{l}\mathrm{Kcna} 1+/-\mathrm{Tau}+/- \\
C 57 B L / 6 \text { mice }\end{array}$ & $\begin{array}{l}\text { Tau loss decreases network hyperexcitability } \\
\text { in Kcna1-/- hippocampal slices exposed } \\
\text { to increased extracellular K + levels. }\end{array}$ & {$[185]$} \\
\hline & $\begin{array}{l}\text { hAPP/Tau+/+, } \\
\text { hAPP/Tau+/-, } \\
\text { hAPP/Tau-/-, } \\
\text { TASD41/Fyn/Tau, } \\
\text { SOD1G93A mice, } \\
\text { amyloid-tau } \\
\text { mouse models }\end{array}$ & $\begin{array}{l}\text { Tau reduction prevents epileptiform bursting } \\
\text { in hippocampal slices. }\end{array}$ & {$[191]$} \\
\hline & hTau-A152T mice & $\begin{array}{l}\text { hTau accumulation increases synaptic } \\
\text { transmission strength and reduces } \\
\text { paired-pulse facilitation. }\end{array}$ & [192] \\
\hline \multirow[t]{3}{*}{$\begin{array}{l}\text { Whole-cell patch } \\
\text { clamp } \\
\text { recordings }\end{array}$} & $\begin{array}{l}\text { hAPP/Tau+/+, } \\
\text { hAPP/Tau+/-, } \\
\text { hAPP/Tau-/-, } \\
\text { TASD41/Fyn/Tau, } \\
\text { SOD1G93A mice, } \\
\text { amyloid-tau } \\
\text { mouse models }\end{array}$ & $\begin{array}{l}\text { Tau reduction prevents abnormalities in } \\
\text { miniature postsynaptic potentials in } \\
\text { dentate granule cells of hAPPJ } 20 \text { mice. } \\
\text { Tau reduction prevents } \\
\text { excitation-inhibition imbalance in dentate } \\
\text { granule cells of hAPPJ } 20 \text { mice. } \\
\text { Tau reduction prevents abnormalities in } \\
\text { synaptic transmission and plasticity in } \\
\text { hAPPJ } 20 \text { mice. }\end{array}$ & {$[191]$} \\
\hline & $\begin{array}{l}\mathrm{rTg} 4510, \mathrm{pR} 5 \text { tau } \\
\text { mouse models }\end{array}$ & $\begin{array}{l}\text { Depolarized action potential initiation and } \\
\text { reduced firing in CA } 1 \text { neurons of two } \\
\text { P301L tau transgenic mouse models. } \\
\text { Reduced firing in rTg } 4510 \text { mice occurs in } \\
\text { the presence of hyperphosphorylated tau } \\
\text { prior to neurodegeneration. }\end{array}$ & [205] \\
\hline & $\begin{array}{l}\text { pR5 tau mouse } \\
\text { model }\end{array}$ & $\begin{array}{l}\text { Reported decreased firing threshold and } \\
\text { reduced LTP behavior }\end{array}$ & [206] \\
\hline \multicolumn{4}{|l|}{ In vitro } \\
\hline $\begin{array}{l}\text { Primary neuronal } \\
\text { culture electro- } \\
\text { physiological } \\
\text { recording }\end{array}$ & $\begin{array}{l}\mathrm{rTg} 4510, \mathrm{pR} 5 \text { tau } \\
\text { mouse models }\end{array}$ & $\begin{array}{l}\text { Pseudo-hyperphosphorylated tau reduces } \\
\text { firing in primary neuronal cultures. }\end{array}$ & [205] \\
\hline $\begin{array}{l}\text { Organotypic cell } \\
\text { culture calcium } \\
\text { imaging }\end{array}$ & hTauAT mice & $\begin{array}{l}\text { Expression of hTauAT elevates intracellular } \\
\mathrm{Ca}^{2+} \text { concentrations in CA3 neurons at } \\
\text { resting state and after membrane } \\
\text { depolarization through NR2B-containing } \\
\text { NMDA receptors. } \\
\text { The hTauAT mutation enhances synaptic } \\
\text { transmission and susceptibility for } \\
\text { epileptiform activity in area CA3 without } \\
\text { affecting synaptic plasticity. }\end{array}$ & {$[272]$} \\
\hline
\end{tabular}

excitability, as the absence of tau has been shown to reduce excitability and increased expression of mutant tau and phosphorylated tau also appears capable of silencing neurons, reducing activity.

It should be noted that several animal models previously used for the development of treatments, and which form the bases for some NH hypotheses, have limitations which diminish their translational validity. In the next section some of the limitations and caveats of the respective animal models that should be considered or controlled as part of the experimental design are addressed. 


\section{A TRANSLATIONAL PERSPECTIVE ON NETWORK HYPEREXCITABILITY IN AD}

\section{Limitations and caveats}

The development of several mouse models with amyloid pathology generally involves the overexpressions of hAPP [209]. Current amyloid mouse models are based on introducing hAPP, in which even overexpression of wild-type hAPP is already associated with neurophysiological effects [210]. In addition to this, the introduction of hAPP compounds the amount of endogenous mouse A $\beta P P$ already being expressed in the neurons [211]. The presence of high levels of $A \beta P P$ would also mean that higher levels of $\mathrm{A} \beta \mathrm{PP}$-associated fragments such as $\mathrm{sA} \beta \mathrm{PP} \alpha$, sA $\beta P P \beta$, amyloid protein fragment eta, and amyloid intracellular domain, would also be elevated in these mouse models. These fragments have been shown to affect synaptic activity [212, 213] as well as amyloidogenesis [214] nontrivially, raising the issue of these fragments confounding some of these interpretations claimed to be derived from amyloid- $\beta$ solely.

A study addressing these confounds by incorporating an inducible switch of $\mathrm{A} \beta \mathrm{PP}$ expression in mice demonstrated that by halting A $\beta P P$ expression, it was able to slow and attenuate the presence of epileptiform-like activity in these mice [215], suggesting the presence of the NH phenotype to be associated with A $\mathrm{PPP}$ and other A $\mathrm{BP}$ fragments rather than amyloid- $\beta$. In concordance with this, a study to reduce amyloid- $\beta$ mediated hyperexcitability by immunotherapy in mice produced the exact opposite effect [129]. These findings suggest that A $\beta P P$, rather than amyloid- $\beta$, might be the causative factor for $\mathrm{NH}$ in these animal models. Another primary argument against the application of A $\beta P P-$ associated mutations in animal models is the fact that these mutations only represent a small fraction of the population of $\mathrm{AD}$ patients. Patients with $\mathrm{AD}$ can be divided into two main categories: those with sporadic AD, which account for approximately $94-99 \%$ of all cases, and those with familial $\mathrm{AD}$, the remaining 6-1\% [216]. The mutations used to induce amyloid pathology in animal models stem from the mutations associated with familial AD and might not or might at least be only partly representative of sporadic AD cases, limiting direct translational potential to many $\mathrm{AD}$ patients. Besides the overexpression of proteins, animal models develop under these conditions from the embryonic stage, altering the development of the animal. If a putative neurophysiological effect arising from the pathology was detected in such an animal, it could be possible that the effect could be due to a different baseline due to the development under these genetic conditions rather than the pathology at that point of time itself. Approaches incorporating the temporal control of the expression of pathologyassociated genes, such as the regulatable rTg4510 tau mice could provide a more physiological approach to study pathological mechanisms and subsequent neurophysiological changes.

As with the generation of amyloid pathology models of $\mathrm{AD}$, mouse models with tau pathology also suffer from some of these caveats and limitations. The tau mutation(s) required to elicit part of the tau pathology reminiscent of AD pathology, are more commonly associated with frontotemporal dementia (FTD) rather than $\mathrm{AD}$ [209, 217]. Given the heterogeneity of tauopathies, tau pathology associated with FTD may have differential effects on hyperexcitability compared to pathological tau associated with $\mathrm{AD}$ [218]. In addition, certain manipulations that involve the phosphorylation state of tau, such as the application of okadaic acid to elicit an increase in tau phosphorylation state [219], can lead to the phosphorylation of other substrates that could alter neuronal excitability. The specificity of some phosphate-related manipulations limits some of the relationships between tau phosphorylation and its effects on hyperexcitability that can be concluded from some of these experiments.

Another unintended effect and confound related to the generation of transgenic animals also involves the incorporation of the transgene construct into the genome of the animal. In a recent example, behavioral and molecular phenotypes originally thought to be associated with tau pathology in the $\mathrm{rTg} 4510$ mouse model were instead associated with gene disruption due to construct insertion [220].

These caveats and their associated research implications provide a critical angle to some of the studies associated with $\mathrm{NH}$ in preclinical models of $\mathrm{AD}$ and challenge some of the underlying assumptions regarding the origin of $\mathrm{NH}$ in $\mathrm{AD}$. Being cognizant of these caveats and potential confounding factors should prevent misleading conclusions from being made.

The studies presented above showcase strong evidence for the presence of $\mathrm{NH}$ in animal models, and to a lesser extent, human patients as well as the implications for the disease. However, due to some of the caveats and limitations associated with animal models, can we be certain that the hyperexcitability 
seen in animal models of pathology faithfully mimics that of the human condition? Here, we present a perspective on evaluating the presence of $\mathrm{NH}$ in animal models of $\mathrm{AD}$, as well as providing some insight into preclinical research tools that should address the uncertainty regarding the validity of $\mathrm{NH}$ in preclinical studies in the next section.

\section{Network hyperexcitability as a marker of $A D$ pathology model validity}

The failure of clinical trials of drugs for AD has highlighted an incomplete understanding of the disease. This could be due to inaccurate animal models that may only superficially resemble the pathological traits of $\mathrm{AD}$ but not the underlying etiology or dysfunction. Perhaps a deeper understanding of the effects of the functional changes associated with pathology, such as NH are necessary. The neurophysiological indication of $\mathrm{NH}$ in $\mathrm{AD}$ may be a factor that links the 'form' of pathology and 'function' (or dysfunction) of neurons in AD. However, since many types of neurological disorders can result in $\mathrm{NH}$, it is key that aspects of hyperexcitability in animal models are relevant to the disease.

As mentioned above, indirect evidence for $\mathrm{NH}$ may be present in human patients in the form of cortical hyperexcitability, hippocampal hyperactivity, and deficits in DMN deactivation. Based on these premises, experiments investigating the presence of $\mathrm{NH}$ in animal models of AD pathology should consider the relevant spatial localization of the $\mathrm{NH}$ (i.e., investigating hippocampal hyperactivity in animal models) in conjunction with the presence or absence of AD-associated pathology to evaluate the validity of the model representing AD-relevant NH. Secondly, the temporal aspects of network activity should also be a feature capitulated by animal models. While it remains to be ascertained that the increase in brain activity in the prodromal phase reflects the phenomenon of $\mathrm{NH}$, this could be an indirect indication. Working on this premise, animal models of AD-associated pathology that exhibit NH should also consider the temporal onset and progression of $\mathrm{NH}$ in relation to overall network activity. By matching not only pathological, but also the neurophysiological change timelines to the temporal progression currently understood from clinical reports, model validity can be reinforced.

The presence of epileptiform and seizure-like activity in $\mathrm{AD}$ is a tantalizing possibility for evaluating the presence of AD-relevant $\mathrm{NH}$ in animal models. However, given the myriad forms of epilepsies and seizures, caution should be exercised in making definitive conclusions regarding seizures, epilepsy, and AD. Further electrophysiological characterization of the seizure type(s) associated with human AD patients in both sporadic and familial forms is suggested before any definitive claims of model validity are made on the basis of seizure-like phenomena. Nonetheless, once validated in humans, this aspect of $\mathrm{NH}$ is expected to be one of the most definitive and promising indications of $\mathrm{NH}$ in animal models.

Cellular and molecular indications of hyperexcitability such as interneuron deficits and dysfunction of glutamate metabolism may also provide an indication of an abnormal state of excitability. Characterization of cellular subtypes and biomolecular assays of brain homogenates, gene expression levels from both AD patients and animal models may lead to more solid basis of increased excitability from a molecular and cellular perspective.

These proposed indications form the initial framework for the evaluation of $\mathrm{NH}$ in animal models. As more research on the electrophysiological nature of $\mathrm{NH}$ emerges, these proposals will become more refined and specific to the human condition.

\section{Further preclinical opportunities for optimizing/validating $\mathrm{NH}$ as an early $A D$ indicator}

The caveats and limitations presented in the previous section in animal models illustrate some potential confounding factors that might preclude a direct translational comparison between current animal models and clinical studies of $\mathrm{AD}$ in terms of $\mathrm{NH}$. By reducing these confounds, certainty regarding the origins of $\mathrm{NH}$ can be elucidated and compared to human observations for a better measure of model validity.

In the cases of animal models of amyloid and tau pathology, the overexpression of the transgenic proteins is the main driving factor of the pathogenesis of the respective pathologies. However, this leads to uncertainty regarding the source of dysfunctions, whether it be due to the pathology itself or the side effects of the transgenic manipulations themselves. Recent developments in animal models of both amyloid and tau pathology may be able to resolve and mitigate this confound to a large extent. 
The generation of knock-in variants of mouse models of amyloid pathology, termed, the APP-KI mice [221], replaces the mouse APP gene with a humanized form and incorporate familial Alzheimer's disease mutations associated with the development of amyloid pathology, such as the Swedish (KM670/671NL) or Iberian (I716F) mutations. These mice develop robust amyloid pathology but exhibit similar amounts of the A $\beta$ PP compared to wild-type mice, eliminating most of the confounding factors associated with the overproduction of A $\beta \mathrm{PP}$-associated fragments and $\mathrm{A} \beta \mathrm{PP}$ itself. In addition, generation of multiple mouse models combining individual APP mutations (e.g., Swedish or Arctic) such as the $A P P^{N L-F}$ or $A P P^{N L}-\mathrm{G}-\mathrm{F}$ mice, increases the amount of $C$ terminal $\beta$ (CTF- $\beta$ ) fragments in a gene-dose response (i.e., $\mathrm{APP} \mathrm{NL}-\mathrm{G}-\mathrm{F}$ mice produce more amyloid- $\beta$ fragments than $A P P^{N L-F}$ mice). This allows for the study of the dose response effects of amyloid- $\beta$ in these mice when comparing $\mathrm{APP}^{\mathrm{NL}-\mathrm{G}-\mathrm{F}}$ and $\mathrm{APP} \mathrm{PL}^{\mathrm{NL}-\mathrm{F}}$ to $\mathrm{APP} \mathrm{PL}^{\mathrm{NL}}$ mice for example. In a recent study by Johnson and colleagues [130] investigating the differential effects of $\mathrm{A} \beta \mathrm{PP}$ overexpression, mouse models exhibiting $\mathrm{A} \beta \mathrm{PP}$ overexpression were compared to APP-KI animals to evaluate the effects of A $\beta P P$ overexpression. The outcomes noted were that while all models exhibited $\mathrm{NH}$ in the form of nonconvulsive seizures, reduction of amyloid- $\beta$ levels in $\mathrm{J} 20$ mice overexpressing A $\beta P P$ did not ameliorate epileptiform activity. This suggests that the presence of NH phenotypes in these mouse models may not be related solely to amyloid- $\beta$ levels but to a confluence of factors involving A $\beta P P$ overexpression and $\mathrm{A} \beta \mathrm{PP}$ processing, which can only be investigated using newer animal models controlling for these factors. However, other reports argue against changes in neuronal activity in APP-KI models in terms of network hyperactivity. Multi-tetrode recordings of entorhinal cortex and hippocampus, revealed equivalent firing frequencies in APP KI mice relative to age-matched wild-type mice [222], while diminished power and phase amplitude-coupling was found in this mouse model [54, 223]. Moreover, the incidence of network hyperexcitability in the form of interictal spikes did not differ between APP-KI ${ }^{\mathrm{NL}-\mathrm{F}}$ mice and wild-type controls [224]. Following from the discussion above regarding the protein overexpression and $\mathrm{NH}$, the evidence stemming from these studies of APP-KI animals does indeed suggest $\mathrm{NH}$ to be driven by $\mathrm{A} \beta \mathrm{PP}$ overexpression rather than by amyloid- $\beta$.
In a similar vein, the generation of mouse models of tau pathology requires the overexpression of the humanized form of the mutant MAPT gene encoding for the tau protein. The mutation which allows the development of tau pathology is derived from the mutation observed in FTD, such as the P301S [225] or P301L [226] mutation. Similar to the APP-KI mice, humanized tau knock-in mice were also produced [227], with the murine MAPT gene replaced by the humanized wild-type MAPT gene. These modifications should reduce confounds of protein overexpression. These mice were reported to be similar to wild-type mice containing murine tau in terms of amyloid- $\beta$ levels, neuronal death, or brain atrophy, suggesting no clear detrimental effects of replacing murine tau with human tau [227]. It should be noted that these mice do not contain any mutations that promote the development of tau pathology, but rather mimic the properties of endogenous human tau without overexpression.

Alternatively, another method of inducing tau pathology exploits the prion-like nature of the pathological form of the protein [228] in tandem with or without transgenic approaches for the induction tau pathology. This method grants to some extent, both temporal and spatial control over where and when tau pathology may be induced, allowing for a more controlled study of the local effects, and spreading of tau pathology. This process, called seeding, involves the injection of tau fragments that promote the aggregation of the tau protein into the pathological form and subsequently propagate it across the brain [8, 229-231]. However, a prerequisite for this seeding process is the expression of transgenic humanized tau containing mutations (e.g., P301S) that confer a predisposition to develop pathology. Several recent reports have investigated the neurophysiological outcomes of this seeding method in various mouse models associated with tau [230, 231]. Recent developments in tau seeding have enabled the induction of tau pathology in mice that do not have a mutant human tau genotype such as wild-type mice [232]. This opens the possibility for more closely mimicking cases of sporadic AD, which do not have direct genetic bases for developing tau pathology and eliminate the confound of altered development, transgenic insertion artefacts, and protein overexpression. Further strengthening this approach is the source from which these seeds are derived. The seeding method described in [232] is directly derived from brain samples taken from patients with $\mathrm{AD}$, thus theoretically resembling the 
tau pathology more closely associated with AD rather than FTD.

These approaches seem to represent a more accurate proxy of combined amyloid and tau pathologies in $\mathrm{AD}$, allowing the field to step closer to discerning the etiology of $\mathrm{NH}$ in $\mathrm{AD}$.

\section{Translational limitations and opportunities for clinical detection of network hyperexcitability}

As briefly described above, conclusively detecting $\mathrm{NH}$ in a clinical setting remains elusive, generally due to the requirement for invasive electrodes to be implanted local to the source of $\mathrm{NH}$. Noninvasive neurophysiological methods such as BOLD fMRI offer insight into indications of network activity, but may suffer from issues such as source localization accuracy, spatial and temporal resolution, as well as difficulty in measuring deeper brain structures [233]. Other methods such as PET involve exposure to doses of radiation and limits the numbers of scans that can be safely performed [233]. Other limitations come in the form of practical methodological challenges relating to measuring hyperexcitability in certain vigilance states, such as sleep, which has been suggested to contain more epileptiform activity [14].

However, which methods are the best suited for the detection of hyperexcitability with minimal discomfort to the patient? Both EEG and MEG are promising techniques for the detection of hyperexcitable phenomena due to the direct measurement of electrical activity generated from network activity. However, depending on the recording montage and recording paradigms, MEG, and purely scalpbased EEG may not be able to identify with sufficient spatial resolution, the source(s) of hyperexcitable activity, especially in deeper brain structures [234, 235]. Several approaches attempting to address the issue of deep source localization in both MEG and EEG have been developed to study deeper brain regions. Some of these include MEG virtual electrodes [236] and high-density scalp EEG recordings [237]. While there is debate regarding which method offers a higher spatial and temporal resolution, MEGbased methods have been reported to outperform EEG-based measures in detecting subclinical epileptiform activity in AD patients [77], as well as predict the conversion from MCI to AD [238, 239].

While both methods have inherent limitations in terms of source localization, the combination of both methods is able to yield better source localization than the usage of a single modality [240]. This combined modality approach has also been successfully applied in the field of epilepsy evaluation [241] and could be an underdeveloped opportunity for the detection of $\mathrm{NH}$ in $\mathrm{AD}$ patients.

\section{CONCLUSIONS AND PERSPECTIVE}

$\mathrm{NH}$ is a pathological feature shared among multiple neuropathological disorders with implications for cognitive function and possibly for neurodegenerative disease progression. Accumulating evidence points to the presence of $\mathrm{NH}$ in patients with $\mathrm{AD}$, hypothesized to impair cognitive, motor, and behavioral function. The links between $\mathrm{NH}$ and amyloid, tau, glutamatergic and interneuron functions have shown multiple pathways by which these pathologies interact, even synergistically, to result in dysfunction. Clinical studies have shown cortical hyperexcitability, alterations in hippocampal activity, increased predisposition to seizure-like activity in $\mathrm{AD}$ as well as changes in inactivation of the DMN which may indicate $\mathrm{NH}$.

Indications of $\mathrm{NH}$ in animal models of AD pathology are emerging as features of model validity. However, studies using animal models of AD pathology have generally involved the application of protein overexpression to induce pathology, which could have NH as a side effect, confounding the interpretation of the relationship between pathology and NH observed in humans and animal models. Recent improvements in model development and molecular approaches to studying $\mathrm{AD}$ pathology alleviate some of these confounds associated with protein overexpression and provide a clearer picture of the source of NH. In addition, care should be exercised when generalizing preclinical outcomes of $\mathrm{NH}$ phenotypes when using animal models that primarily model the familial form of AD or FTD rather than sporadic AD. It is possible that the $\mathrm{NH}$ phenotypes in AD may even differ between familial and sporadic instances of the disease.

$\mathrm{NH}$ is a very promising indicator of network dysfunction in patients of $\mathrm{AD}$ and may serve as a prodromal indicator of $\mathrm{AD}$ pathogenesis. By understanding and aligning the source of $\mathrm{NH}$ in patients and in animal models, we can obtain a key biomarker of $\mathrm{AD}$ progression that correlates with cognitive dysfunction and pathology. 


\section{ACKNOWLEDGMENTS}

This project has received funding from the European Union's Horizon 2020 research and innovation programme under the Marie Skłodowska-Curie actions grant agreement no. 765549 , project 'MGATE'.

This manuscript has been submitted in the framework of the Mini Forum organized by Electrophysiology Professional Interest Area of ISTA ART-Alzheimer's Association.

The authors declare that they are working for Janssen Pharmaceutica NV.

Authors' disclosures available online (https:// www.j-alz.com/manuscript-disclosures/21-0397r2).

\section{REFERENCES}

[1] Amarouch MY, Abriel H (2015) Cellular hyperexcitability caused by mutations that alter the activation process of voltage-gated sodium channels. Front Physiol 6, 45 .

[2] Kumar SS, Buckmaster PS (2006) Hyperexcitability, interneurons, and loss of GABAergic synapses in entorhinal cortex in a model of temporal lobe epilepsy. J Neurosci 26, 4613-4623.

[3] Parpura V, Verkhratsky A (2012) The astrocyte excitability brief: From receptors to gliotransmission. Neurochem Int 61, 610-621.

[4] Galimberti D, Scarpini E (2010) Treatment of Alzheimer's disease: Symptomatic and disease-modifying approaches. Curr Aging Sci 3, 46-56.

[5] Mehta D, Jackson R, Paul G, Shi J, Sabbagh M (2017) Why do trials for Alzheimer's disease drugs keep failing? A discontinued drug perspective for 2010-2015. Expert Opin Investig Drugs 26, 735-739.

[6] Sasaguri H, Nilsson P, Hashimoto S, Nagata K, Saito T, De Strooper B, Hardy J, Vassar R, Winblad B, Saido TC (2017) APP mouse models for Alzheimer's disease preclinical studies. EMBO J 36, 2473-2487.

[7] DeKosky ST, Marek K (2003) Looking backward to move forward: Early detection of neurodegenerative disorders. Science 302, 830-834.

[8] Walsh C, Drinkenburg WH, Ahnaou A (2017) Neurophysiological assessment of neural network plasticity and connectivity: Progress towards early functional biomarkers for disease interception therapies in Alzheimer's disease. Neurosci Biobehav Rev 73, 340-358.

[9] Braak H, Alafuzoff I, Arzberger T, Kretzschmar H, Del Tredici K (2006) Staging of Alzheimer disease-associated neurofibrillary pathology using paraffin sections and immunocytochemistry. Acta Neuropathol 112, 389-404.

[10] Heneka MT, Carson MJ, El Khoury J, Landreth GE, Brosseron F, Feinstein DL, Jacobs AH, Wyss-Coray T, Vitorica J, Ransohoff RM, Herrup K, Frautschy SA, Finsen B, Brown GC, Verkhratsky A, Yamanaka K, Koistinaho J, Latz E, Halle A, Petzold GC, Town T, Morgan D, Shinohara ML, Perry VH, Holmes C, Bazan NG, Brooks DJ, Hunot S, Joseph B, Deigendesch N, Garaschuk O, Boddeke E, Dinarello CA, Breitner JC, Cole GM,
Golenbock DT, Kummer MP (2015) Neuroinflammation in Alzheimer's disease. Lancet Neurol 14, 388-405.

[11] Crews L, Masliah E (2010) Molecular mechanisms of neurodegeneration in Alzheimer's disease. Hum Mol Genet 19, R12-R20.

[12] Bateman RJ, Xiong C, Benzinger TLS, Fagan AM, Goate A, Fox NC, Marcus DS, Cairns NJ, Xie X, Blazey TM, Holtzman DM, Santacruz A, Buckles V, Oliver A, Moulder K, Aisen PS, Ghetti B, Klunk WE, McDade E, Martins RN, Masters CL, Mayeux R, Ringman JM, Rossor MN, Schofield PR, Sperling RA, Salloway S, Morris JC; Dominantly Inherited Alzheimer Network (2012) Clinical and biomarker changes in dominantly inherited Alzheimer's disease. N Engl J Med 367, 795-804.

[13] Greicius MD, Srivastava G, Reiss AL, Menon V (2004) Default-mode network activity distinguishes Alzheimer's disease from healthy aging: Evidence from functional MRI. Proc Natl Acad Sci U S A 101, 4637-4642.

[14] Vossel KA, Tartaglia MC, Nygaard HB, Zeman AZ, Miller BL (2017) Epileptic activity in Alzheimer's disease: Causes and clinical relevance. Lancet Neurol 16, 311-322.

[15] Engels MMA, van der Flier WM, Stam CJ, Hillebrand A, Scheltens P, van Straaten ECW (2017) Alzheimer's disease: The state of the art in resting-state magnetoencephalography. Clin Neurophysiol 128, 1426-1437.

[16] Dauwels J, Srinivasan K, Ramasubba Reddy M, Musha T, Vialatte FB, Latchoumane C, Jeong J, Cichocki A (2011) Slowing and loss of complexity in Alzheimer's EEG: Two sides of the same coin? Int J Alzheimers Dis 2011, 539621.

[17] Corriveau-Lecavalier N, Mellah S, Clément F, Belleville S (2019) Evidence of parietal hyperactivation in individuals with mild cognitive impairment who progressed to dementia: A longitudinal fMRI study. Neuroimage Clin 24, 101958.

[18] Kazim SF, Chuang SC, Zhao W, Wong RKS, Bianchi R, Iqbal K (2017) Early-onset network hyperexcitability in presymptomatic Alzheimer's disease transgenic mice is suppressed by passive immunization with anti-human APP/A $\beta$ antibody and by mGluR5 blockade. Front Aging Neurosci 9, 71.

[19] Minkeviciene R, Rheims S, Dobszay MB, Zilberter M, Hartikainen J, Fülöp L, Penke B, Zilberter Y, Harkany T, Pitkänen A, Tanila H (2009) Amyloid $\beta$-induced neuronal hyperexcitability triggers progressive epilepsy. J Neurosci 29, 3453-3462.

[20] Palop JJ, Chin J, Roberson ED, Wang J, Thwin MT, BienLy N, Yoo J, Ho KO, Yu GQ, Kreitzer A, Finkbeiner S, Noebels JL, Mucke L (2007) Aberrant excitatory neuronal activity and compensatory remodeling of inhibitory hippocampal circuits in mouse models of Alzheimer's disease. Neuron 55, 697-711.

[21] Harris SS, Wolf F, De Strooper B, Busche MA (2020) Tipping the scales: Peptide-dependent dysregulation of neural circuit dynamics in Alzheimer's disease. Neuron 107, 417-435.

[22] Bakker A, Krauss GL, Albert MS, Speck CL, Jones LR, Stark CE, Yassa MA, Bassett SS, Shelton AL, Gallagher M (2012) Reduction of hippocampal hyperactivity improves cognition in amnestic mild cognitive impairment. Neuron 74, 467-474.

[23] Bero AW, Yan P, Roh JH, Cirrito JR, Stewart FR, Raichle ME, Lee JM, Holtzman DM (2011) Neuronal activity regulates the regional vulnerability to amyloid- $\beta$ deposition. Nat Neurosci 14, 750-756. 
[24] Courchesne E, Pierce K, Schumann CM, Redcay E, Buckwalter JA, Kennedy DP, Morgan J (2007) Mapping early brain development in autism. Neuron 56, 399-413.

[25] Lepeta K, Lourenco MV, Schweitzer BC, Martino Adami PV, Banerjee P, Catuara-Solarz S, de La Fuente Revenga M, Guillem AM, Haidar M, Ijomone OM, Nadorp B, Qi L, Perera ND, Refsgaard LK, Reid KM, Sabbar M, Sahoo A, Schaefer N, Sheean RK, Suska A, Verma R, Vicidomini C, Wright D, Zhang X, Seidenbecher C (2016) Synaptopathies: Synaptic dysfunction in neurological disorders - a review from students to students. J Neurochem 138, 785-805.

[26] Hasan S, Balobaid A, Grottesi A, Dabbagh O, Cenciarini $\mathrm{M}$, Rawashdeh $\mathrm{R}, \mathrm{Al}$-Sagheir A, Bove C, Macchioni L, Pessia M, Al-Owain M, D'Adamo MC (2017) Lethal digenic mutations in the $K+$ channels Kir4.1 (KCNJ10) and SLACK (KCNT1) associated with severe-disabling seizures and neurodevelopmental delay. J Neurophysiol 118, 2402-2411.

[27] Dong X, Wang Y, Qin Z (2009) Molecular mechanisms of excitotoxicity and their relevance to pathogenesis of neurodegenerative diseases. Acta Pharmacol Sin 30, 379-387.

[28] Spitzer NC (2006) Electrical activity in early neuronal development. Nature 444, 707-712.

[29] Bromfield EB, Cavazos JE, Sirven JI (2006) An Introduction to Epilepsy. Chapter 1. Basic Mechanisms Underlying Seizures and Epilepsy, American Epilepsy Society, West Hartford, CT.

[30] Isbrandt D (2017) A mechanistic link between glia and neuronal excitability in acute neuroinflammation. $J$ Physiol 595, 603-604.

[31] Buzsáki G, Draguhn A (2004) Neuronal oscillations in cortical networks. Science 304, 1926-1929.

[32] Llinas RR (1988) The intrinsic electrophysiological properties of mammalian neurons: Insights into central nervous system function. Science 242, 1654-1664.

[33] Jobert M, Wilson FJ, Ruigt GS, Brunovsky M, Prichep LS, Drinkenburg WH; IPEG Pharmaco-EEG Guidelines Committee (2012) Guidelines for the recording and evaluation of pharmaco-EEG data in man: The International Pharmaco-EEG Society (IPEG). Neuropsychobiology 66, 201-220.

[34] Ahnaou A, Huysmans H, Jacobs T, Drinkenburg WH (2014) Cortical EEG oscillations and network connectivity as efficacy indices for assessing drugs with cognition enhancing potential. Neuropharmacology 86, 362-377.

[35] Babiloni C, Barry RJ, Başar E, Blinowska KJ, Cichocki A, Drinkenburg WHIM, Klimesch W, Knight RT, Lopes da Silva F, Nunez P, Oostenveld R, Jeong J, PascualMarqui R, Valdes-Sosa P, Hallett M (2020) International Federation of Clinical Neurophysiology (IFCN) - EEG research workgroup: Recommendations on frequency and topographic analysis of resting state EEG rhythms. Part 1: Applications in clinical research studies. Clin Neurophysiol 131, 285-307.

[36] Wilson HR, Cowan JD (1972) Excitatory and inhibitory interactions in localized populations of model neurons. Biophys J 12, 1-24.

[37] Wilson HR, Cowan JD (1973) A mathematical theory of the functional dynamics of cortical and thalamic nervous tissue. Kybernetik 13, 55-80.

[38] Zijlmans M, Jiruska P, Zelmann R, Leijten FSS, Jefferys JGR, Gotman J (2012) High-frequency oscillations as a new biomarker in epilepsy. Ann Neurol 71, 169-178.
[39] Shuman T, Amendolara B, Golshani P (2017) Theta rhythmopathy as a cause of cognitive disability in TLE. Epilepsy Curr 17, 107-111.

[40] Kitchigina VF (2018) Alterations of coherent theta and gamma network oscillations as an early biomarker of temporal lobe epilepsy and Alzheimer's disease. Front Integr Neurosci 12, 36.

[41] Klein AS, Donoso JR, Kempter R, Schmitz D, Beed P (2016) Early cortical changes in gamma oscillations in Alzheimer's disease. Front Syst Neurosci 10, 83.

[42] Koelewijn L, Bompas A, Tales A, Brookes MJ, Muthukumaraswamy SD, Bayer A, Singh KD (2017) Alzheimer's disease disrupts alpha and beta-band resting-state oscillatory network connectivity. Clin Neurophysiol 128, 2347-2357.

[43] Dauwels J, Vialatte F, Musha T, Cichocki A (2010) A comparative study of synchrony measures for the early diagnosis of Alzheimer's disease based on EEG. Neuroimage 49, 668-693.

[44] Arbab T, Battaglia FP, Pennartz CMA, Bosman CA (2018) Abnormal hippocampal theta and gamma hypersynchrony produces network and spike timing disturbances in the Fmr1-KO mouse model of Fragile X syndrome. Neurobiol Dis 114, 65-73.

[45] van der Molen MJW, Stam CJ, van der Molen MW (2014) Resting-state EEG oscillatory dynamics in fragile $\mathrm{X}$ syndrome: Abnormal functional connectivity and brain network organization. PLoS One $\mathbf{9}$, e88451.

[46] Wang J, Ethridge LE, Mosconi MW, White SP, Binder DK, Pedapati EV, Erickson CA, Byerly MJ, Sweeney JA (2017) A resting EEG study of neocortical hyperexcitability and altered functional connectivity in fragile $\mathrm{X}$ syndrome. $J$ Neurodev Disord $\mathbf{9}, 11$.

[47] Little S, Brown P (2014) The functional role of beta oscillations in Parkinson's disease. Parkinsonism Relat Disord 20(Suppl 1), S44-S48.

[48] Ethridge LE, White SP, Mosconi MW, Wang J, Pedapati EV, Erickson CA, Byerly MJ, Sweeney JA (2017) Neural synchronization deficits linked to cortical hyperexcitability and auditory hypersensitivity in fragile $\mathrm{X}$ syndrome. Mol Autism 8, 22.

[49] Leung H, Zhu CX, Chan DT, Poon WS, Shi L, Mok VC, Wong LK (2015) Ictal high-frequency oscillations and hyperexcitability in refractory epilepsy. Clin Neurophysiol 126, 2049-2057.

[50] Demont-Guignard S, Benquet P, Gerber U, Biraben A, Martin B, Wendling F (2012) Distinct hyperexcitability mechanisms underlie fast ripples and epileptic spikes. Ann Neurol 71, 342-352.

[51] Jafari Z, Kolb BE, Mohajerani MH (2020) Neural oscillations and brain stimulation in Alzheimer's disease. Prog Neurobiol 194, 101878.

[52] Verret L, Mann EO, Hang GB, Barth AMI, Cobos I, Ho K, Devidze N, Masliah E, Kreitzer AC, Mody I, Mucke L, Palop JJ (2012) Inhibitory interneuron deficit links altered network activity and cognitive dysfunction in Alzheimer model. Cell 149, 708-721.

[53] Martinez-Losa M, Tracy TE, Ma K, Verret L, ClementePerez A, Khan AS, Cobos I, Ho K, Gan L, Mucke L, Alvarez-Dolado M, Palop JJ (2018) Nav1.1overexpressing interneuron transplants restore brain rhythms and cognition in a mouse model of Alzheimer's disease. Neuron 98, 75-89.e5.

[54] Nakazono T, Lam TN, Patel AY, Kitazawa M, Saito T, Saido TC, Igarashi KM (2017) Impaired in vivo gamma 
oscillations in the medial entorhinal cortex of knock-in Alzheimer model. Front Syst Neurosci 11, 48.

[55] Cramer PE, Cirrito JR, Wesson DW, Daniel Lee CY, Karlo JC, Zinn AE, Casali BT, Restivo JL, Goebel WD, James MJ, Brunden KR, Wilson DA, Landreth GE (2012) ApoE-directed therapeutics rapidly clear $\beta$-amyloid and reverse deficits in AD mouse models. Science 335, 1503-1506.

[56] Busche MA, Kekuš M, Adelsberger H, Noda T, Förstl H, Nelken I, Konnerth A (2015) Rescue of long-range circuit dysfunction in Alzheimer's disease models. Nat Neurosci 18, 1623-1630.

[57] Smailovic U, Koenig T, Kåreholt I, Andersson T, Kramberger MG, Winblad B, Jelic V (2018) Quantitative EEG power and synchronization correlate with Alzheimer's disease CSF biomarkers. Neurobiol Aging 63, 88-95.

[58] Wang J, Fang Y, Wang X, Yang H, Yu X, Wang H (2017) Enhanced gamma activity and cross-frequency interaction of resting-state electroencephalographic oscillations in patients with Alzheimer's disease. Front Aging Neurosci 9, 243.

[59] Babiloni C, Carducci F, Lizio R, Vecchio F, Baglieri A, Bernardini S, Cavedo E, Bozzao A, Buttinelli C, Esposito F, Giubilei F, Guizzaro A, Marino S, Montella P, Quattrocchi CC, Redolfi A, Soricelli A, Tedeschi G, Ferri R, Rossi-Fedele G, Ursini F, Scrascia F, Vernieri F, Pedersen TJ, Hardemark H-G, Rossini PM, Frisoni GB (2013) Resting state cortical electroencephalographic rhythms are related to gray matter volume in subjects with mild cognitive impairment and Alzheimer's disease. Hum Brain Mapp 34, 1427-1446.

[60] Babiloni C, Lizio R, Carducci F, Vecchio F, Redolfi A, Marino S, Tedeschi G, Montella P, Guizzaro A, Esposito F, Bozzao A, Giubilei F, Orzi F, Quattrocchi CC, Soricelli A, Salvatore E, Baglieri A, Bramanti P, Cavedo E, Ferri R, Cosentino F, Ferrara M, Mundi C, Grilli G, Pugliese S, Gerardi G, Parisi L, Vernieri F, Triggiani AI, Pedersen JT, Hårdemark HG, Rossini PM, Frisoni GB (2011) Resting state cortical electroencephalographic rhythms and white matter vascular lesions in subjects with Alzheimer's disease: An Italian multicenter study. J Alzheimers Dis 26, 331-346.

[61] Busche MA, Konnerth A (2016) Impairments of neural circuit function in Alzheimer's disease. Philos Trans $R$ Soc Lond B Biol Sci 371, 20150429.

[62] Sutula T (2002) Seizure-induced axonal sprouting: Assessing connections between injury, local circuits, and epileptogenesis. Epilepsy Curr 2, 86-91.

[63] Knierim JJ (2015) The hippocampus. Curr Biol 25, R1116-R1121.

[64] Kotti T, Riekkinen PJ, Miettinen R (1997) Characterization of target cells for aberrant mossy fiber collaterals in the dentate gyrus of epileptic rat. Exp Neurol 146, 323-330.

[65] Acsády L, Kamondi A, Sík A, Freund T, Buzsáki G (1998) GABAergic cells are the major postsynaptic targets of mossy fibers in the rat hippocampus. J Neurosci 18, 33863403.

[66] Buckmaster PS, Dudek FE (1999) In vivo intracellular analysis of granule cell axon reorganization in epileptic rats. J Neurophysiol 81, 712-721.

[67] Lehmann TN, Gabriel S, Eilers A, Njunting M, Kovacs R, Schulze K, Lanksch WR, Heinemann U (2001) Fluorescent tracer in pilocarpine-treated rats shows widespread aberrant hippocampal neuronal connectivity. Eur J Neurosci 14, 83-95.
[68] Putcha D, Brickhouse M, O'Keefe K, Sullivan C, Rentz D, Marshall G, Dickerson B, Sperling R (2011) Hippocampal hyperactivation associated with cortical thinning in Alzheimer's disease signature regions in non-demented elderly adults. $J$ Neurosci 31, 17680-17688.

[69] Setti SE, Hunsberger HC, Reed MN (2017) Alterations in hippocampal activity and Alzheimer's disease. Transl Issues Psychol Sci 3, 348-356.

[70] Pennisi G, Ferri R, Lanza G, Cantone M, Pennisi M, Puglisi V, Malaguarnera G, Bella R (2011) Transcranial magnetic stimulation in Alzheimer's disease: A neurophysiological marker of cortical hyperexcitability. $J$ Neural Transm (Vienna) 118, 587-598.

[71] Celone KA, Calhoun VD, Dickerson BC, Atri A, Chua EF, Miller SL, DePeau K, Rentz DM, Selkoe DJ, Blacker D, Albert MS, Sperling RA (2006) Alterations in memory networks in mild cognitive impairment and Alzheimer's disease: An independent component analysis. J Neurosci 26, 10222-10231.

[72] Rombouts SARB, Barkhof F, Goekoop R, Stam CJ, Scheltens P (2005) Altered resting state networks in mild cognitive impairment and mild Alzheimer's disease: An fMRI study. Hum Brain Mapp 26, 231-239.

[73] Di Lazzaro V, Oliviero A, Pilato F, Saturno E, Dileone M, Marra C, Daniele A, Ghirlanda S, Gainotti G, Tonali PA (2004) Motor cortex hyperexcitability to transcranial magnetic stimulation in Alzheimer's disease. J Neurol Neurosurg Psychiatry 75, 555-559.

[74] Dickerson BC, Salat DH, Greve DN, Chua EF, RandGiovannetti E, Rentz DM, Bertram L, Mullin K, Tanzi RE, Blacker D, Albert MS, Sperling RA (2005) Increased hippocampal activation in mild cognitive impairment compared to normal aging and AD. Neurology 65, 404-411.

[75] Filippini N, MacIntosh BJ, Hough MG, Goodwin GM, Frisoni GB, Smith SM, Matthews PM, Beckmann CF, Mackay CE (2009) Distinct patterns of brain activity in young carriers of the APOE-epsilon4 allele. Proc Natl Acad Sci U S A 106, 7209-7214.

[76] Quiroz YT, Budson AE, Celone K, Ruiz A, Newmark R, Castrillón G, Lopera F, Stern CE (2010) Hippocampal hyperactivation in presymptomatic familial Alzheimer's disease. Ann Neurol 68, 865-875.

[77] Toniolo S, Sen A, Husain M (2020) Modulation of brain hyperexcitability: Potential new therapeutic approaches in Alzheimer's disease. Int J Mol Sci 21, 9318.

[78] Klink K, Jaun U, Federspiel A, Wunderlin M, Teunissen CE, Kiefer C, Wiest R, Scharnowski F, Sladky R, Haugg A, Hellrung L, Peter J (2021) Targeting hippocampal hyperactivity with real-time fMRI neurofeedback: Protocol of a single-blind randomized controlled trial in mild cognitive impairment. BMC Psychiatry 21, 87.

[79] Tahmasian M, Pasquini L, Scherr M, Meng C, Förster S, Mulej Bratec S, Shi K, Yakushev I, Schwaiger M, Grimmer T, Diehl-Schmid J, Riedl V, Sorg C, Drzezga A (2015) The lower hippocampus global connectivity, the higher its local metabolism in Alzheimer disease. Neurology 84, 1956-1963.

[80] Bondi MW, Houston WS, Eyler LT, Brown GG (2005) fMRI evidence of compensatory mechanisms in older adults at genetic risk for Alzheimer disease. Neurology 64, 501-508.

[81] Miller SL, Fenstermacher E, Bates J, Blacker D, Sperling RA, Dickerson BC (2008) Hippocampal activation in adults with mild cognitive impairment predicts 
subsequent cognitive decline. J Neurol Neurosurg Psychiatry 79, 630-635.

[82] Takeuchi N, Izumi SI (2012) Maladaptive plasticity for motor recovery after stroke: Mechanisms and approaches. Neural Plasticity 2012, e359728.

[83] Small GW, Kepe V, Ercoli LM, Siddarth P, Bookheimer SY, Miller KJ, Lavretsky H, Burggren AC, Cole GM, Vinters HV, Thompson PM, Huang SC, Satyamurthy N, Phelps ME, Barrio JR (2006) PET of brain amyloid and tau in mild cognitive impairment. $N$ Engl J Med 355, 2652-2663.

[84] Kennedy KM, Rodrigue KM, Devous MD, Hebrank AC, Bischof GN, Park DC (2012) Effects of beta-amyloid accumulation on neural function during encoding across the adult lifespan. Neuroimage 62, 1-8.

[85] Mormino EC, Brandel MG, Madison CM, Marks S, Baker SL, Jagust WJ (2012) A $\beta$ deposition in aging is associated with increases in brain activation during successful memory encoding. Cereb Cortex 22, 1813-1823.

[86] Huijbers W, Schultz AP, Papp KV, LaPoint MR, Hanseeuw B, Chhatwal JP, Hedden T, Johnson KA, Sperling RA (2019) Tau accumulation in clinically normal older adults is associated with hippocampal hyperactivity. J Neurosci 39, 548-556.

[87] Elman JA, Oh H, Madison CM, Baker SL, Vogel JW, Marks SM, Crowley S, O’Neil JP, Jagust WJ (2014) Neural compensation in older people with brain amyloid- $\beta$ deposition. Nat Neurosci 17, 1316-1318.

[88] Huijbers W, Mormino EC, Wigman SE, Ward AM, Vannini P, McLaren DG, Becker JA, Schultz AP, Hedden T, Johnson KA, Sperling RA (2014) Amyloid deposition is linked to aberrant entorhinal activity among cognitively normal older adults. J Neurosci 34, 5200-5210.

[89] Rieck JR, Rodrigue KM, Kennedy KM, Devous MD, Park DC (2015) The effect of beta-amyloid on face processing in young and old adults: A multivariate analysis of the BOLD signal. Hum Brain Mapp 36, 2514-2526.

[90] Mevel K, Chételat G, Eustache F, Desgranges B (2011) The default mode network in healthy aging and Alzheimer's disease. Int J Alzheimers Dis 2011, 535816.

[91] Sperling R, Mormino E, Johnson K (2014) The evolution of preclinical Alzheimer's disease: Implications for prevention trials. Neuron 84, 608-622.

[92] Raichle ME (2015) The brain's default mode network. Annu Rev Neurosci 38, 433-447.

[93] Anticevic A, Cole MW, Murray JD, Corlett PR, Wang XJ, Krystal JH (2012) The role of default network deactivation in cognition and disease. Trends Cogn Sci 16, 584-592.

[94] Maddock RJ, Garrett AS, Buonocore MH (2001) Remembering familiar people: The posterior cingulate cortex and autobiographical memory retrieval. Neuroscience 104, 667-676.

[95] Raichle ME, MacLeod AM, Snyder AZ, Powers WJ, Gusnard DA, Shulman GL (2001) A default mode of brain function. Proc Natl Acad Sci U S A 98, 676-682.

[96] Anticevic A, Repovs G, Shulman GL, Barch DM (2010) When less is more: TPJ and default network deactivation during encoding predicts working memory performance. Neuroimage 49, 2638-2648.

[97] Daselaar SM, Prince SE, Cabeza R (2004) When less means more: Deactivations during encoding that predict subsequent memory. Neuroimage 23, 921-927.

[98] White TP, Jansen M, Doege K, Mullinger KJ, Park SB, Liddle EB, Gowland PA, Francis ST, Bowtell R, Liddle PF (2013) Theta power during encoding predicts subsequent-memory performance and default mode network deactivation. Hum Brain Mapp 34, 2929-2943.

[99] Wang K, Liang M, Wang L, Tian L, Zhang X, Li K, Jiang T (2007) Altered functional connectivity in early Alzheimer's disease: A resting-state fMRI study. Hum Brain Mapp 28, 967-978.

[100] Agosta F, Pievani M, Geroldi C, Copetti M, Frisoni GB, Filippi M (2012) Resting state fMRI in Alzheimer's disease: Beyond the default mode network. Neurobiol Aging 33, 1564-1578.

[101] Sorg C, Riedl V, Mühlau M, Calhoun VD, Eichele T, Läer L, Drzezga A, Förstl H, Kurz A, Zimmer C, Wohlschläger AM (2007) Selective changes of resting-state networks in individuals at risk for Alzheimer's disease. Proc Natl Acad Sci U S A 104, 18760-18765.

[102] Brier MR, Thomas JB, Snyder AZ, Benzinger TL, Zhang D, Raichle ME, Holtzman DM, Morris JC, Ances BM (2012) Loss of intranetwork and internetwork resting state functional connections with Alzheimer's disease progression. J Neurosci 32, 8890-8899.

[103] Petrella JR, Sheldon FC, Prince SE, Calhoun VD, Doraiswamy PM (2011) Default mode network connectivity in stable vs progressive mild cognitive impairment. Neurology 76, 511-517.

[104] Zhang HY, Wang SJ, Liu B, Ma ZL, Yang M, Zhang ZJ, Teng GJ (2010) Resting brain connectivity: Changes during the progress of Alzheimer disease. Radiology 256, 598-606.

[105] Persson J, Lind J, Larsson A, Ingvar M, Sleegers K, Van Broeckhoven C, Adolfsson R, Nilsson LG, Nyberg L (2008) Altered deactivation in individuals with genetic risk for Alzheimer's disease. Neuropsychologia 46, 1679-1687.

[106] Lustig C, Snyder AZ, Bhakta M, O'Brien KC, McAvoy M, Raichle ME, Morris JC, Buckner RL (2003) Functional deactivations: Change with age and dementia of the Alzheimer type. Proc Natl Acad Sci U S A 100, 14504-14509.

[107] Wang L, Zang Y, He Y, Liang M, Zhang X, Tian L, Wu T, Jiang T, Li K (2006) Changes in hippocampal connectivity in the early stages of Alzheimer's disease: Evidence from resting state fMRI. Neuroimage 31, 496-504.

[108] Pasquini L, Scherr M, Tahmasian M, Myers NE, Ortner M, Kurz A, Förstl H, Zimmer C, Grimmer T, Akhrif A, Wohlschläger AM, Riedl V, Sorg C (2016) Increased intrinsic activity of medial-temporal lobe subregions is associated with decreased cortical thickness of medial-parietal areas in patients with Alzheimer's disease dementia. J Alzheimers Dis 51, 313-326.

[109] Najm R, Jones EA, Huang Y (2019) Apolipoprotein E4, inhibitory network dysfunction, and Alzheimer's disease. Mol Neurodegener 14, 24.

[110] Sperling RA, LaViolette PS, O'Keefe K, O’Brien J, Rentz DM, Pihlajamaki M, Marshall G, Hyman BT, Selkoe DJ, Hedden T, Buckner RL, Becker JA, Johnson KA (2009) Amyloid deposition is associated with impaired default network function in older persons without dementia. $\mathrm{Neu}$ ron 63, 178-188.

[111] Collins JD, Henley SMD, Suárez-González A (2020) A systematic review of the prevalence of depression, anxiety, and apathy in frontotemporal dementia, atypical and young-onset Alzheimer's disease, and inherited dementia. Int Psychogeriatr, doi: 10.1017/S1041610220001118

[112] Kim J, Kim YK (2021) Crosstalk between depression and dementia with resting-state fMRI studies and its 
relationship with cognitive functioning. Biomedicines 9, 82 .

[113] Benschop L, Poppa T, Medani T, Shahabi H, Baeken C, Leahy RM, Pizzagalli DA, Vanderhasselt MA (2021) Electrophysiological scarring in remitted depressed patients: Elevated EEG functional connectivity between the posterior cingulate cortex and the subgenual prefrontal cortex as a neural marker for rumination. J Affect Disord 281, 493-501.

[114] de Carvalho M, de Mendonça A, Miranda PC, Garcia C, Luís ML (1997) Magnetic stimulation in Alzheimer's disease. J Neurol 244, 304-307.

[115] Liepert J, Bär KJ, Meske U, Weiller C (2001) Motor cortex disinhibition in Alzheimer's disease. Clin Neurophysiol 112, 1436-1441.

[116] Schliebs R, Arendt T (2011) The cholinergic system in aging and neuronal degeneration. Behav Brain Res 221, 555-563.

[117] Mesulam MM (2013) Cholinergic circuitry of the human nucleus basalis and its fate in Alzheimer's disease. J Comp Neurol 521, 4124-4144.

[118] Selden NR, Gitelman DR, Salamon-Murayama N, Parrish TB, Mesulam MM (1998) Trajectories of cholinergic pathways within the cerebral hemispheres of the human brain. Brain 121 (Pt 12), 2249-2257.

[119] Ferreri F, Pauri F, Pasqualetti P, Fini R, Forno GD, Rossini PM (2003) Motor cortex excitability in Alzheimer's disease: A transcranial magnetic stimulation study. Ann Neurol 53, 102-108.

[120] Hess G, Krawczyk R (1996) Cholinergic modulation of synaptic transmission in horizontal connections of rat motor cortex. Acta Neurobiol Exp (Wars) 56, 863-872.

[121] Scharfman HE (2007) The neurobiology of epilepsy. Curr Neurol Neurosci Rep 7, 348-354.

[122] Pandis D, Scarmeas N (2012) Seizures in Alzheimer disease: Clinical and epidemiological data. Epilepsy Curr 12, 184-187.

[123] Romanelli MF, Morris JC, Ashkin K, Coben LA (1990) Advanced Alzheimer's disease is a risk factor for lateonset seizures. Arch Neurol 47, 847-850.

[124] Förstl H, Burns A, Levy R, Cairns N, Luthert P, Lantos P (1992) Neurologic signs in Alzheimer's disease. Results of a prospective clinical and neuropathologic study. Arch Neurol 49, 1038-1042.

[125] Risse SC, Lampe TH, Bird TD, Nochlin D, Sumi SM, Keenan T, Cubberley L, Peskind E, Raskind MA (1990) Myoclonus, seizures, and paratonia in Alzheimer disease. Alzheimer Dis Assoc Disord 4, 217-225.

[126] Mendez M, Lim G (2003) Seizures in elderly patients with dementia: Epidemiology and management. Drugs Aging 20, 791-803.

[127] Scarmeas N, Honig LS, Choi H, Cantero J, Brandt J, Blacker D, Albert M, Amatniek JC, Marder K, Bell K, Hauser WA, Stern Y (2009) Seizures in Alzheimer disease: Who, when, and how common? Arch Neurol 66, 992-997.

[128] Jiruska P, de Curtis M, Jefferys JG, Schevon CA, Schiff SJ, Schindler K (2013) Synchronization and desynchronization in epilepsy: Controversies and hypotheses. J Physiol 591, 787-797.

[129] Busche MA, Grienberger C, Keskin AD, Song B, Neumann U, Staufenbiel M, Förstl H, Konnerth A (2015) Decreased amyloid- $\beta$ and increased neuronal hyperactivity by immunotherapy in Alzheimer's models. Nat Neurosci 18, 1725-1727.
[130] Johnson ECB, Ho K, Yu GQ, Das M, Sanchez PE, Djukic B, Lopez I, Yu X, Gill M, Zhang W, Paz JT, Palop JJ, Mucke L (2020) Behavioral and neural network abnormalities in human APP transgenic mice resemble those of App knock-in mice and are modulated by familial Alzheimer's disease mutations but not by inhibition of BACE1. Mol Neurodegener 15, 53.

[131] Horváth A, Szucs A, Barcs G, Noebels JL, Kamondi A (2016) Epileptic seizures in Alzheimer disease: A review. Alzheimer Dis Assoc Disord 30, 186-192.

[132] Mendez MF, Catanzaro P, Doss RC, ARguello R, Frey WH (1994) Seizures in Alzheimer's disease: Clinicopathologic study. J Geriatr Psychiatry Neurol 7, 230-233.

[133] Rao SC, Dove G, Cascino GD, Petersen RC (2009) Recurrent seizures in patients with dementia: Frequency, seizure types, and treatment outcome. Epilepsy Behav 14, 118-120.

[134] Blum DE, Eskola J, Bortz JJ, Fisher RS (1996) Patient awareness of seizures. Neurology 47, 260-264.

[135] Palop JJ, Mucke L (2009) Epilepsy and cognitive impairments in Alzheimer disease. Arch Neurol 66, 435-440.

[136] Vossel KA, Beagle AJ, Rabinovici GD, Shu H, Lee SE, Naasan G, Hegde M, Cornes SB, Henry ML, Nelson AB, Seeley WW, Geschwind MD, Gorno-Tempini ML, Shih T, Kirsch HE, Garcia PA, Miller BL, Mucke L (2013) Seizures and epileptiform activity in the early stages of Alzheimer disease. JAMA Neurol 70, 1158-1166.

[137] Vossel KA, Ranasinghe KG, Beagle AJ, Mizuiri D, Honma SM, Dowling AF, Darwish SM, Berlo VV, Barnes DE, Mantle M, Karydas AM, Coppola G, Roberson ED, Miller BL, Garcia PA, Kirsch HE, Mucke L, Nagarajan SS (2016) Incidence and impact of subclinical epileptiform activity in Alzheimer's disease. Ann Neurol 80, 858-870.

[138] Busche MA, Eichhoff G, Adelsberger H, Abramowski D, Wiederhold KH, Haass C, Staufenbiel M, Konnerth A, Garaschuk O (2008) Clusters of hyperactive neurons near amyloid plaques in a mouse model of Alzheimer's disease. Science 321, 1686-1689.

[139] Texidó L, Martín-Satué M, Alberdi E, Solsona C, Matute C (2011) Amyloid $\beta$ peptide oligomers directly activate NMDA receptors. Cell Calcium 49, 184-190.

[140] Palmer AM, Gershon S (1990) Is the neuronal basis of Alzheimer's disease cholinergic or glutamatergic? FASEB $J$ 4, 2745-2752.

[141] Revett TJ, Baker GB, Jhamandas J, Kar S (2013) Glutamate system, amyloid $\beta$ peptides and tau protein: Functional interrelationships and relevance to Alzheimer disease pathology. J Psychiatry Neurosci 38, 6-23.

[142] Lewerenz J, Maher P (2015) Chronic glutamate toxicity in neurodegenerative diseases-what is the evidence? Front Neurosci 9, 469.

[143] Zott B, Simon MM, Hong W, Unger F, Chen-Engerer HJ, Frosch MP, Sakmann B, Walsh DM, Konnerth A (2019) A vicious cycle of amyloid $\beta$-dependent neuronal hyperactivation. Science $\mathbf{3 6 5}, 559-565$.

[144] Li S, Hong S, Shepardson NE, Walsh DM, Shankar GM, Selkoe D (2009) Soluble oligomers of amyloid $\beta$-protein facilitate hippocampal long-term depression by disrupting neuronal glutamate uptake. Neuron 62, 788-801.

[145] Danysz W, Parsons CG (2012) Alzheimer's disease, $\beta$ amyloid, glutamate, NMDA receptors and memantine - searching for the connections. Br J Pharmacol 167, 324-352. 
[146] Caraci F, Nicoletti F, Copani A (2018) Metabotropic glutamate receptors: The potential for therapeutic applications in Alzheimer's disease. Curr Opin Pharmacol 38, 1-7.

[147] Blanchard BJ, Thomas VL, Ingram VM (2002) Mechanism of membrane depolarization caused by the Alzheimer A $\beta 1-42$ peptide. Biochem Biophy Res Commun 293, 1197-1203.

[148] Nitsch RM, Deng A, Wurtman RJ, Growdon JH (1997) Metabotropic glutamate receptor subtype mGlur1 $\alpha$ stimulates the secretion of the amyloid $\beta$-protein precursor ectodomain. J Neurochem 69, 704-712.

[149] Arias C, Arrieta I, Tapia R (1995) Beta-amyloid peptide fragment 25-35 potentiates the calcium-dependent release of excitatory amino acids from depolarized hippocampal slices. J Neurosci Res 41, 561-566.

[150] Kabogo D, Rauw G, Amritraj A, Baker G, Kar S (2010) $\beta$ Amyloid-related peptides potentiate $K+$-evoked glutamate release from adult rat hippocampal slices. Neurobiol Aging 31, 1164-1172.

[151] Parpura-Gill A, Beitz D, Uemura E (1997) The inhibitory effects of beta-amyloid on glutamate and glucose uptakes by cultured astrocytes. Brain Res 754, 65-71.

[152] Scimemi A, Meabon JS, Woltjer RL, Sullivan JM, Diamond JS, Cook DG (2013) Amyloid- $\beta 1-42$ slows clearance of synaptically released glutamate by mislocalizing astrocytic GLT-1. J Neurosci 33, 5312-5318.

[153] Esposito Z, Belli L, Toniolo S, Sancesario G, Bianconi C, Martorana A (2013) Amyloid $\beta$, glutamate, excitotoxicity in Alzheimer's disease: Are we on the right track? CNS Neurosci Ther 19, 549-555.

[154] Wang R, Reddy PH (2017) Role of glutamate and NMDA receptors in Alzheimer's disease. J Alzheimers Dis 57, 1041-1048.

[155] Choi DW (1987) Ionic dependence of glutamate neurotoxicity. J Neurosci 7, 369-379.

[156] Choi DW, Koh JY, Peters S (1988) Pharmacology of glutamate neurotoxicity in cortical cell culture: Attenuation by NMDA antagonists. J Neurosci 8, 185-196.

[157] Kelsom C, Lu W (2013) Development and specification of GABAergic cortical interneurons. Cell Biosci 3, 19.

[158] Palop JJ, Mucke L (2016) Network abnormalities and interneuron dysfunction in Alzheimer disease. Nat Rev Neurosci 17, 777-792.

[159] Hollnagel JO, Elzoheiry S, Gorgas K, Kins S, Beretta CA, Kirsch J, Kuhse J, Kann O, Kiss E (2019) Early alterations in hippocampal perisomatic GABAergic synapses and network oscillations in a mouse model of Alzheimer's disease amyloidosis. PLoS One 14, e0209228.

[160] Hijazi S, Heistek TS, Scheltens P, Neumann U, Shimshek DR, Mansvelder HD, Smit AB, van Kesteren RE (2019) Early restoration of parvalbumin interneuron activity prevents memory loss and network hyperexcitability in a mouse model of Alzheimer's disease. Mol Psychiatry 25, 3380-3398.

[161] Buzsáki G, Wang XJ (2012) Mechanisms of gamma oscillations. Annu Rev Neurosci 35, 203-225.

[162] Fries P (2005) A mechanism for cognitive dynamics: Neuronal communication through neuronal coherence. Trends Cogn Sci 9, 474-480.

[163] Fries P (2009) Neuronal gamma-band synchronization as a fundamental process in cortical computation. Аппи Rev Neurosci 32, 209-224.

[164] Wang XJ (2010) Neurophysiological and computational principles of cortical rhythms in cognition. Physiol Rev 90, 1195-1268.
[165] Rubio SE, Vega-Flores G, Martínez A, Bosch C, PérezMediavilla A, del Río J, Gruart A, Delgado-García JM, Soriano E, Pascual M (2012) Accelerated aging of the GABAergic septohippocampal pathway and decreased hippocampal rhythms in a mouse model of Alzheimer's disease. FASEB J 26, 4458-4467.

[166] Goutagny R, Gu N, Cavanagh C, Jackson J, Chabot JG, Quirion R, Krantic S, Williams S (2013) Alterations in hippocampal network oscillations and theta-gamma coupling arise before $A \beta$ overproduction in a mouse model of Alzheimer's disease. Eur J Neurosci 37, 1896-1902.

[167] Stam CJ, van Cappellen van Walsum AM, Pijnenburg YA, Berendse HW, de Munck JC, Scheltens P, van Dijk BW (2002) Generalized synchronization of MEG recordings in Alzheimer's disease: Evidence for involvement of the gamma band. J Clin Neurophysiol 19, 562-574.

[168] Herrmann CS, Demiralp T (2005) Human EEG gamma oscillations in neuropsychiatric disorders. Clin Neurophysiol 116, 2719-2733.

[169] van Deursen JA, Vuurman EF, Verhey FR, van KranenMastenbroek VH, Riedel WJ (2008) Increased EEG gamma band activity in Alzheimer's disease and mild cognitive impairment. J Neural Transm (Vienna) 115, 1301-1311.

[170] Iaccarino HF, Singer AC, Martorell AJ, Rudenko A, Gao F, Gillingham TZ, Mathys H, Seo J, Kritskiy O, Abdurrob F, Adaikkan C, Canter RG, Rueda R, Brown EN, Boyden ES, Tsai LH (2016) Gamma frequency entrainment attenuates amyloid load and modifies microglia. Nature $\mathbf{5 4 0}$, 230-235.

[171] Magloire V, Mercier MS, Kullmann DM, Pavlov I (2018) GABAergic interneurons in seizures: Investigating causality with optogenetics. Neuroscientist 25, 344-358.

[172] Schevon CA, Weiss SA, McKhann G, Goodman RR, Yuste R, Emerson RG, Trevelyan AJ (2012) Evidence of an inhibitory restraint of seizure activity in humans. Nat Commun 3, 1060.

[173] Reyes-Marin KE, Nuñez A (2017) Seizure susceptibility in the APP/PS1 mouse model of Alzheimer's disease and relationship with amyloid $\beta$ plaques. Brain Res 1677, 93-100.

[174] Gureviciene I, Ishchenko I, Ziyatdinova S, Jin N, Lipponen A, Gurevicius K, Tanila H (2019) Characterization of epileptic spiking associated with brain amyloidosis in APP/PS1 mice. Front Neurol 10, 1151.

[175] Kam K, Duffy ÁM, Moretto J, LaFrancois JJ, Scharfman HE (2016) Interictal spikes during sleep are an early defect in the $\mathrm{Tg} 2576$ mouse model of $\beta$-amyloid neuropathology. Sci Rep 6, 20119.

[176] Busche MA, Chen X, Henning HA, Reichwald J, Staufenbiel M, Sakmann B, Konnerth A (2012) Critical role of soluble amyloid- $\beta$ for early hippocampal hyperactivity in a mouse model of Alzheimer's disease. Proc Natl Acad Sci U S A 109, 8740-8745.

[177] Tamagnini F, Scullion S, Brown JT, Randall AD (2015) Intrinsic excitability changes induced by acute treatment of hippocampal CA1 pyramidal neurons with exogenous amyloid $\beta$ peptide. Hippocampus 25, 786-797.

[178] Šišková Z, Justus D, Kaneko H, Friedrichs D, Henneberg N, Beutel T, Pitsch J, Schoch S, Becker A, von der Kammer H, Remy S (2014) Dendritic structural degeneration is functionally linked to cellular hyperexcitability in a mouse model of Alzheimer's disease. Neuron 84, 1023-1033.

[179] Cirrito JR, Yamada KA, Finn MB, Sloviter RS, Bales KR, May PC, Schoepp DD, Paul SM, Mennerick S, Holtzman 
DM (2005) Synaptic activity regulates interstitial fluid amyloid-beta levels in vivo. Neuron 48, 913-922.

[180] Grienberger C, Rochefort NL, Adelsberger H, Henning HA, Hill DN, Reichwald J, Staufenbiel M, Konnerth A (2012) Staged decline of neuronal function in vivo in an animal model of Alzheimer's disease. Nat Commun 3, 774.

[181] Pallo SP, DiMaio J, Cook A, Nilsson B, Johnson GVW (2016) Mechanisms of tau and $A \beta$-induced excitotoxicity. Brain Res 1634, 119-131.

[182] McGowan E, Eriksen J, Hutton M (2006) A decade of modeling Alzheimer's disease in transgenic mice. Trends Genet 22, 281-289.

[183] He Z, Guo JL, McBride JD, Narasimhan S, Kim H, Changolkar L, Zhang B, Gathagan RJ, Yue C, Dengler C, Stieber A, Nitla M, Coulter DA, Abel T, Brunden KR, Trojanowski JQ, Lee VM (2018) Amyloid- $\beta$ plaques enhance Alzheimer's brain tau-seeded pathologies by facilitating neuritic plaque tau aggregation. Nat Med 24, 29-38.

[184] Hall AM, Throesch BT, Buckingham SC, Markwardt SJ, Peng Y, Wang Q, Hoffman DA, Roberson ED (2015) Taudependent Kv4.2 depletion and dendritic hyperexcitability in a mouse model of Alzheimer's disease. J Neurosci 35, 6221-6230.

[185] Holth JK, Bomben VC, Reed JG, Inoue T, Younkin L, Younkin SG, Pautler RG, Botas J, Noebels JL (2013) Tau loss attenuates neuronal network hyperexcitability in mouse and Drosophila genetic models of epilepsy. J Neurosci 33, 1651-1659.

[186] Tai XY, Koepp M, Duncan JS, Fox N, Thompson P, Baxendale S, Liu JY, Reeves C, Michalak Z, Thom M (2016) Hyperphosphorylated tau in patients with refractory epilepsy correlates with cognitive decline: A study of temporal lobe resections. Brain 139, 2441-2455.

[187] Ittner A, Chua SW, Bertz J, Volkerling A, van der Hoven J, Gladbach A, Przybyla M, Bi M, van Hummel A, Stevens CH, Ippati S, Suh LS, Macmillan A, Sutherland G, Kril JJ, Silva AP, Mackay JP, Poljak A, Delerue F, Ke YD, Ittner LM (2016) Site-specific phosphorylation of tau inhibits amyloid- $\beta$ toxicity in Alzheimer's mice. Science 354, 904-908.

[188] Busche MA, Wegmann S, Dujardin S, Commins C, Schiantarelli J, Klickstein N, Kamath TV, Carlson GA, Nelken I, Hyman BT (2019) Tau impairs neural circuits, dominating amyloid- $\beta$ effects, in Alzheimer models in vivo. Nat Neurosci 22, 57-64.

[189] Guo T, Noble W, Hanger DP (2017) Roles of tau protein in health and disease. Acta Neuropathol 133, 665-704.

[190] Roberson ED, Scearce-Levie K, Palop JJ, Yan F, Cheng IH, Wu T, Gerstein H, Yu GQ, Mucke L (2007) Reducing endogenous tau ameliorates amyloid beta-induced deficits in an Alzheimer's disease mouse model. Science 316, 750-754.

[191] Roberson ED, Halabisky B, Yoo JW, Yao J, Chin J, Yan F, Wu T, Hamto P, Devidze N, Yu GQ, Palop JJ, Noebels JL, Mucke L (2011) Amyloid- $\beta /$ Fyn-induced synaptic, network, and cognitive impairments depend on tau levels in multiple mouse models of Alzheimer's disease. J Neurosci 31, 700-711.

[192] Maeda S, Djukic B, Taneja P, Yu G, Lo I, Davis A, Craft R, Guo W, Wang X, Kim D, Ponnusamy R, Gill TM, Masliah E, Mucke L (2016) Expression of A152T human tau causes age-dependent neuronal dysfunction and loss in transgenic mice. EMBO Rep 17, 530-551.

[193] Hunsberger HC, Rudy CC, Batten SR, Gerhardt GA, Reed $\mathrm{MN}$ (2015) P301L tau expression affects glutamate release and clearance in the hippocampal trisynaptic pathway. $J$ Neurochem 132, 169-182.

[194] Marinković P, Blumenstock S, Goltstein PM, Korzhova V, Peters F, Knebl A, Herms J (2019) In vivo imaging reveals reduced activity of neuronal circuits in a mouse tauopathy model. Brain 142, 1051-1062.

[195] Ciupek SM, Cheng J, Ali YO, Lu HC, Ji D (2015) Progressive functional impairments of hippocampal neurons in a tauopathy mouse model. J Neurosci 35, 8118-8131.

[196] Sun XY, Tuo QZ, Liuyang ZY, Xie AJ, Feng XL, Yan X, Qiu M, Li S, Wang XL, Cao FY, Wang XC, Wang JZ, Liu R (2016) Extrasynaptic NMDA receptor-induced tau overexpression mediates neuronal death through suppressing survival signaling ERK phosphorylation. Cell Death Dis 7, e2449.

[197] Esclaire F, Lesort M, Blanchard C, Hugon J (1997) Glutamate toxicity enhances tau gene expression in neuronal cultures. J Neurosci Res 49, 309-318.

[198] Ittner LM, Ke YD, Delerue F, Bi M, Gladbach A, van Eersel J, Wölfing H, Chieng BC, Christie MJ, Napier IA, Eckert A, Staufenbiel M, Hardeman E, Götz J (2010) Dendritic function of tau mediates amyloid-beta toxicity in Alzheimer's disease mouse models. Cell 142, 387-397.

[199] Kobayashi S, Tanaka T, Soeda Y, Almeida OFX, Takashima A (2017) Local somatodendritic translation and hyperphosphorylation of tau protein triggered by AMPA and NMDA receptor stimulation. EBioMedicine 20, 120-126.

[200] DeVos SL, Goncharoff DK, Chen G, Kebodeaux CS, Yamada K, Stewart FR, Schuler DR, Maloney SE, Wozniak DF, Rigo F, Bennett CF, Cirrito JR, Holtzman DM, Miller TM (2013) Antisense reduction of tau in adult mice protects against seizures. J Neurosci 33, 12887-12897.

[201] Ramsden M, Kotilinek L, Forster C, Paulson J, McGowan E, SantaCruz K, Guimaraes A, Yue M, Lewis J, Carlson G, Hutton M, Ashe KH (2005) Age-dependent neurofibrillary tangle formation, neuron loss, and memory impairment in a mouse model of human tauopathy (P301L). J Neurosci 25, 10637-10647.

[202] Fu H, Rodriguez GA, Herman M, Emrani S, Nahmani E, Barrett G, Figueroa HY, Goldberg E, Hussaini SA, Duff KE (2017) Tau pathology induces excitatory neuron loss, grid cell dysfunction, and spatial memory deficits reminiscent of early Alzheimer's disease. Neuron 93, 533-541.e5.

[203] Cheng J, Ji D (2013) Rigid firing sequences undermine spatial memory codes in a neurodegenerative mouse model. Elife 2, e00647.

[204] Rodriguez GA, Barrett GM, Duff KE, Hussaini SA (2020) Chemogenetic attenuation of neuronal activity in the entorhinal cortex reduces $\mathrm{A} \beta$ and tau pathology in the hippocampus. PLoS Biol 18, e3000851.

[205] Hatch RJ, Wei Y, Xia D, Götz J (2017) Hyperphosphorylated tau causes reduced hippocampal CA1 excitability by relocating the axon initial segment. Acta Neuropathol 133, 717-730.

[206] Müller-Thomsen L, Borgmann D, Morcinek K, Schröder S, Dengler B, Moser N, Neumaier F, Schneider T, Schröder $\mathrm{H}$, Huggenberger S (2020) Consequences of hyperphosphorylated tau on the morphology and excitability of hippocampal neurons in aged tau transgenic mice. $\mathrm{Neu}$ robiol Aging 93, 109-123.

[207] Hoover BR, Reed MN, Su J, Penrod RD, Kotilinek LA, Grant MK, Pitstick R, Carlson GA, Lanier LM, Yuan LL, Ashe KH, Liao D (2010) Tau mislocalization to 
dendritic spines mediates synaptic dysfunction independently of neurodegeneration. Neuron 68, 1067-1081.

[208] Mondragón-Rodríguez S, Salas-Gallardo A, GonzálezPereyra P, Macías M, Ordaz B, Peña-Ortega F, Aguilar-Vázquez A, Orta-Salazar E, Díaz-Cintra S, Perry G, Williams S (2018) Phosphorylation of tau protein correlates with changes in hippocampal theta oscillations and reduces hippocampal excitability in Alzheimer's model. $J$ Biol Chem 293, 8462-8472.

[209] Hall AM, Roberson ED (2012) Mouse models of Alzheimer's disease. Brain Res Bull 88, 3-12.

[210] Simón A-M, Schiapparelli L, Salazar-Colocho P, Cuadrado-Tejedor M, Escribano L, López de Maturana R, Del Río J, Pérez-Mediavilla A, Frechilla D (2009) Overexpression of wild-type human APP in mice causes cognitive deficits and pathological features unrelated to $A \beta$ levels. Neurobiol Dis 33, 369-378.

[211] Kokjohn TA, Roher AE (2009) Amyloid precursor protein transgenic mouse models and Alzheimer's disease: Understanding the paradigms, limitations and contributions. Alzheimers Dement 5, 340-347.

[212] Willem M, Tahirovic S, Busche MA, Ovsepian SV, Chafai M, Kootar S, Hornburg D, Evans LDB, Moore S, Daria A, Hampel H, Müller V, Giudici C, Nuscher B, WenningerWeinzierl A, Kremmer E, Heneka MT, Thal DR, Giedraitis V, Lannfelt L, Müller U, Livesey FJ, Meissner F, Herms J, Konnerth A, Marie H, Haass C (2015) $\eta$-Secretase processing of APP inhibits neuronal activity in the hippocampus. Nature 526, 443-447.

[213] Chasseigneaux S, Allinquant B (2012) Functions of A $\beta$, sAPP $\alpha$ and sAPP $\beta$ : Similarities and differences. $J$ Neurochem 120(Suppl 1), 99-108.

[214] Obregon D, Hou H, Deng J, Giunta B, Tian J, Darlington D, Shahaduzzaman M, Zhu Y, Mori T, Mattson MP, Tan J (2012) sAPP- $\alpha$ modulates $\beta$-secretase activity and amyloid- $\beta$ generation. Nat Commun 3, 777 .

[215] Born HA, Kim JY, Savjani RR, Das P, Dabaghian YA, Guo Q, Yoo JW, Schuler DR, Cirrito JR, Zheng H, Golde TE, Noebels JL, Jankowsky JL (2014) Genetic suppression of transgenic APP rescues hypersynchronous network activity in a mouse model of Alzheimer's disease. J Neurosci 34, 3826-3840.

[216] Bekris LM, Yu CE, Bird TD, Tsuang DW (2010) Genetics of Alzheimer disease. J Geriatr Psychiatry Neurol 23, 213-227.

[217] Yasuda M, Yokoyama K, Nakayasu T, Nishimura Y, Matsui M, Yokoyama T, Miyoshi K, Tanaka C (2000) A Japanese patient with frontotemporal dementia and parkinsonism by a tau P301S mutation. Neurology 55, 1224-1227.

[218] Narasimhan S, Guo JL, Changolkar L, Stieber A, McBride JD, Silva LV, He Z, Zhang B, Gathagan RJ, Trojanowski JQ, Lee VMY (2017) Pathological tau strains from human brains recapitulate the diversity of tauopathies in nontransgenic mouse brain. $J$ Neurosci 37, 11406-11423.

[219] Kamat PK, Rai S, Swarnkar S, Shukla R, Ali S, Najmi AK, Nath C (2013) Okadaic acid-induced Tau phosphorylation in rat brain: Role of NMDA receptor. Neuroscience 238, 97-113.

[220] Gamache J, Benzow K, Forster C, Kemper L, Hlynialuk C, Furrow E, Ashe KH, Koob MD (2019) Factors other than hTau overexpression that contribute to tauopathy-like phenotype in rTg4510 mice. Nat Commun 10, 2479.

[221] Saito T, Matsuba Y, Mihira N, Takano J, Nilsson P, Itohara S, Iwata N, Saido TC (2014) Single App knock-in mouse models of Alzheimer's disease. Nat Neurosci 17, 661-663.

[222] Jun H, Bramian A, Soma S, Saito T, Saido TC, Igarashi KM (2020) Disrupted place cell remapping and impaired grid cells in a knockin model of Alzheimer's disease. Neuron 107, 1095-1112.e6.

[223] Jacob S, Davies G, Bock MD, Hermans B, Wintmolders C, Bottelbergs A, Borgers M, Theunis C, Broeck BV, Manyakov NV, Balschun D, Drinkenburg WHIM (2019) Neural oscillations during cognitive processes in an App knock-in mouse model of Alzheimer's disease pathology. Sci Rep 9, 16363.

[224] Brown R, Lam AD, Gonzalez-Sulser A, Ying A, Jones M, Chou RC, Tzioras M, Jordan CY, Jedrasiak-Cape I, Hemonnot AL, Abou Jaoude M, Cole AJ, Cash SS, Saito T, Saido T, Ribchester RR, Hashemi K, Oren I (2018) Circadian and brain state modulation of network hyperexcitability in Alzheimer's disease. eNeuro 5, ENEURO.0426-17.2018.

[225] Yoshiyama Y, Higuchi M, Zhang B, Huang S-M, Iwata N, Saido TC, Maeda J, Suhara T, Trojanowski JQ, Lee VM (2007) Synapse loss and microglial activation precede tangles in a P301S tauopathy mouse model. Neuron 53, 337-351.

[226] Lewis J, McGowan E, Rockwood J, Melrose H, Nacharaju P, Van Slegtenhorst M, Gwinn-Hardy K, Paul Murphy M, Baker M, Yu X, Duff K, Hardy J, Corral A, Lin WL, Yen SH, Dickson DW, Davies P, Hutton M (2000) Neurofibrillary tangles, amyotrophy and progressive motor disturbance in mice expressing mutant (P301L) tau protein. Nat Genet 25, 402-405.

[227] Saito T, Mihira N, Matsuba Y, Sasaguri H, Hashimoto S, Narasimhan S, Zhang B, Murayama S, Higuchi M, Lee VMY, Trojanowski JQ, Saido TC (2019) Humanization of the entire murine Mapt gene provides a murine model of pathological human tau propagation. J Biol Chem 294, 12754-12765.

[228] Mudher A, Colin M, Dujardin S, Medina M, Dewachter I, Alavi Naini SM, Mandelkow EM, Mandelkow E, Buée L, Goedert M, Brion JP (2017) What is the evidence that tau pathology spreads through prion-like propagation? Acta Neuropathol Commun 5, 99.

[229] Guo JL, Lee VM (2011) Seeding of normal tau by pathological tau conformers drives pathogenesis of Alzheimer-like tangles. J Biol Chem 286, 15317-15331.

[230] Ahnaou A, Moechars D, Raeymaekers L, Biermans R, Manyakov NV, Bottelbergs A, Wintmolders C, Van Kolen K, Van De Casteele T, Kemp JA, Drinkenburg WH (2017) Emergence of early alterations in network oscillations and functional connectivity in a tau seeding mouse model of Alzheimer's disease pathology. Sci Rep 7, 14189.

[231] Ahnaou A, Walsh C, Manyakov NV, Youssef SA, Drinkenburg WH (2019) Early electrophysiological disintegration of hippocampal neural networks in a novel locus coeruleus tau-seeding mouse model of Alzheimer's disease. Neural Plast 2019, 6981268.

[232] Guo JL, Narasimhan S, Changolkar L, He Z, Stieber A, Zhang B, Gathagan RJ, Iba M, McBride JD, Trojanowski JQ, Lee VMY (2016) Unique pathological tau conformers from Alzheimer's brains transmit tau pathology in nontransgenic mice. J Exp Med 213, 2635-2654.

[233] Crosson B, Ford A, McGregor KM, Meinzer M, Cheshkov S, Li X, Walker-Batson D, Briggs RW (2010) Functional imaging and related techniques: An introduction for rehabilitation researchers. J Rehabil Res Dev 47, vii-xxxiv. 
[234] Michel CM, Brunet D (2019) EEG source imaging: A practical review of the analysis steps. Front Neurol 10, 325.

[235] Wendel K, Väisänen O, Malmivuo J, Gencer NG, Vanrumste B, Durka P, Magjarević R, Supek S, Pascu ML, Fontenelle H, Grave de Peralta Menendez R (2009) EEG/MEG source imaging: Methods, challenges, and open issues. Comput Intell Neurosci 2009, 656092.

[236] Engels MM, Hillebrand A, van der Flier WM, Stam CJ, Scheltens P, van Straaten EC (2016) Slowing of hippocampal activity correlates with cognitive decline in early onset Alzheimer's disease. An MEG study with virtual electrodes. Front Hum Neurosci 10, 238.

[237] Seeber M, Cantonas LM, Hoevels M, Sesia T, Visser-Vandewalle V, Michel CM (2019) Subcortical electrophysiological activity is detectable with high-density EEG source imaging. Nat Commun 10, 753.

[238] Maestú F, Campo P, Gil-Gregorio P, Fernández S, Fernández A, Ortiz T (2006) Medial temporal lobe neuromagnetic hypoactivation and risk for developing cognitive decline in elderly population: A 2-year follow-up study. Neurobiol Aging 27, 32-37.

[239] Maestú F, Cuesta P, Hasan O, Fernandéz A, Funke M, Schulz PE (2019) The importance of the validation of M/EEG with current biomarkers in Alzheimer's disease. Front Hum Neurosci 13, 17.

[240] Hong JH, Ahn M, Kim K, Jun SC (2013) Localization of coherent sources by simultaneous MEG and EEG beamformer. Med Biol Eng Comput 51, 1121-1135.

[241] Chowdhury RA, Pellegrino G, Aydin Ü, Lina JM, Dubeau F, Kobayashi E, Grova C (2018) Reproducibility of EEGMEG fusion source analysis of interictal spikes: Relevance in presurgical evaluation of epilepsy. Hum Brain Mapp 39, 880-901.

[242] Kelley BJ, Petersen RC (2007) Alzheimer's disease and mild cognitive impairment. Neurol Clin 25, 577-609.

[243] Scarmeas N, Hadjigeorgiou GM, Papadimitriou A, Dubois B, Sarazin M, Brandt J, Albert M, Marder K, Bell K, Honig LS, Wegesin D, Stern Y (2004) Motor signs during the course of Alzheimer disease. Neurology 63, 975-982.

[244] Noebels JL (2011) A perfect storm: Converging paths of epilepsy and Alzheimer's dementia intersect in the hippocampal formation. Epilepsia 52 Suppl 1, 39-46.

[245] Pihlajamäki M, Sperling RA (2009) Functional MRI assessment of task-induced deactivation of the default mode network in Alzheimer's disease and at-risk older individuals. Behav Neurol 21, 77-91.

[246] Wainger BJ, Kiskinis E, Mellin C, Wiskow O, Han SSW, Sandoe J, Perez NP, Williams LA, Lee S, Boulting G, Berry JD, Brown RH, Cudkowicz ME, Bean BP, Eggan K, Woolf CJ (2014) Intrinsic membrane hyperexcitability of amyotrophic lateral sclerosis patient-derived motor neurons. Cell Rep 7, 1-11.

[247] Shibuya K, Park SB, Geevasinga N, Huynh W, Simon NG, Menon P, Howells J, Garg N, Noto Y, Iwai Y, Nicholson GA, Vucic S, Kuwabara S, Kiernan MC (2016) 7. Pathophysiological basis of motor neuronal hyperexcitability in amyotrophic lateral sclerosis. Clin Neurophysiol 127, e12.

[248] Hermann B, Seidenberg M (2007) Epilepsy and cognition. Epilepsy Curr 7, 1-6.

[249] Stafstrom CE, Carmant L (2015) Seizures and epilepsy: An overview for neuroscientists. Cold Spring Harb Perspect Med 5, a022426.

[250] Pawley AD, Chowdhury FA, Tangwiriyasakul C, Ceronie B, Elwes RDC, Nashef L, Richardson MP (2017) Cortical excitability correlates with seizure control and epilepsy duration in chronic epilepsy. Ann Clin Transl Neurol 4, 87-97.

[251] Badawy RA, Vogrin SJ, Lai A, Cook MJ (2013) The cortical excitability profile of temporal lobe epilepsy. Epilepsia 54, 1942-1949.

[252] McCormick DA, Contreras D (2001) On the cellular and network bases of epileptic seizures. Annu Rev Physiol 63, 815-846.

[253] Huddleston LB, Visootsak J, Sherman SL (2014) Cognitive aspects of fragile $\mathrm{X}$ syndrome. Wiley Interdiscip Rev Cogn Sci 5, 501-508.

[254] Ciaccio C, Fontana L, Milani D, Tabano S, Miozzo M, Esposito S (2017) Fragile X syndrome: A review of clinical and molecular diagnoses. Ital J Pediatr 43, 39.

[255] Watson GS, Leverenz JB (2010) Profile of cognitive impairment in Parkinson disease. Brain Pathol 20, 640-645.

[256] Anderson KE (2004) Behavioral disturbances in Parkinson's disease. Dialogues Clin Neurosci 6, 323-332.

[257] Sveinbjornsdottir S (2016) The clinical symptoms of Parkinson's disease. J Neurochem 139, 318-324.

[258] Yu H, Sternad D, Corcos DM, Vaillancourt DE (2007) Role of hyperactive cerebellum and motor cortex in Parkinson's disease. Neuroimage 35, 222-233.

[259] Berger-Sweeney J (2011) Cognitive deficits in Rett syndrome: What we know and what we need to know to treat them. Neurobiol Learn Mem 96, 637-646.

[260] Ahmed R (2007) Clinical profile of five patients with Rett syndrome and literature review. Oman Med $\mathrm{J} 22$, 64-66.

[261] Krajnc N, Zidar J (2016) The role of transcranial magnetic stimulation in evaluation of motor cortex excitability in Rett syndrome. Eur J Paediatr Neurol 20, 597-603.

[262] Yamanouchi H, Kaga M, Arima M (1993) Abnormal cortical excitability in Rett syndrome. Pediatr Neurol 9, 202-206.

[263] Gwak YS, Hulsebosch CE (2011) Neuronal hyperexcitability: A substrate for central neuropathic pain after spinal cord injury. Curr Pain Headache Rep 15, 215-222.

[264] Carron SF, Alwis DS, Rajan R (2016) Traumatic brain injury and neuronal functionality changes in sensory cortex. Front Syst Neurosci 10, 47.

[265] Arciniegas DB, Held K, Wagner P (2002) Cognitive impairment following traumatic brain injury. Curr Treat Options Neurol 4, 43-57.

[266] McAllister TW (2011) Neurobiological consequences of traumatic brain injury. Dialogues Clin Neurosci 13, 287-300.

[267] Lerdkrai C, Asavapanumas N, Brawek B, Kovalchuk Y, Mojtahedi N, Olmedillas del Moral M, Garaschuk O (2018) Intracellular $\mathrm{Ca} 2+$ stores control in vivo neuronal hyperactivity in a mouse model of Alzheimer's disease. Proc Natl Acad Sci U S A 115, E1279-E1288.

[268] Davis KE, Fox S, Gigg J (2014) Increased hippocampal excitability in the 3xTgAD mouse model for Alzheimer's disease in vivo. PLoS One 9, e91203.

[269] Bezzina C, Verret L, Juan C, Remaud J, Halley H, Rampon C, Dahan L (2015) Early onset of hypersynchronous network activity and expression of a marker of chronic seizures in the $\operatorname{Tg} 2576$ mouse model of Alzheimer's disease. PLoS One 10, e0119910.

[270] Hazra A, Gu F, Aulakh A, Berridge C, Eriksen JL, Ziburkus J (2013) Inhibitory neuron and hippocampal 
circuit dysfunction in an aged mouse model of Alzheimer's disease. PLoS One 8, e64318.

[271] Liu C, Tan FCK, Xiao ZC, Dawe GS (2015) Amyloid precursor protein enhances Nav1.6 sodium channel cell surface expression. J Biol Chem 290, 12048-12057.
[272] Decker JM, Krüger L, Sydow A, Dennissen FJ, Siskova Z, Mandelkow E, Mandelkow E-M (2016) The Tau/A152T mutation, a risk factor for frontotemporal-spectrum disorders, leads to NR2B receptor-mediated excitotoxicity. EMBO Rep 17, 552-569. 